\title{
Study of influence of yeast cells treatment on sugarcane ethanol fermentation: Operating conditions and kinetics
}

Yamakawa, Celina Kiyomi; Ccopa Rivera, Elmer; Kwon, Hyun; Herrera Agudelo, William E.; Saad, Marcelo B.W.; Leal, Jairo; Rossell, Carlos E.V.; Bonomi, Antonio; Maciel Filho, Rubens

Published in:

Biochemical Engineering Journal

Link to article, DOI:

10.1016/j.bej.2019.03.022

Publication date:

2019

Document Version

Peer reviewed version

Link back to DTU Orbit

Citation (APA):

Yamakawa, C. K., Ccopa Rivera, E., Kwon, H., Herrera Agudelo, W. E., Saad, M. B. W., Leal, J., Rossell, C. E. V., Bonomi, A., \& Maciel Filho, R. (2019). Study of influence of yeast cells treatment on sugarcane ethanol fermentation: Operating conditions and kinetics. Biochemical Engineering Journal, 147, 1-10. https://doi.org/10.1016/j.bej.2019.03.022

\section{General rights}

Copyright and moral rights for the publications made accessible in the public portal are retained by the authors and/or other copyright owners and it is a condition of accessing publications that users recognise and abide by the legal requirements associated with these rights.

- Users may download and print one copy of any publication from the public portal for the purpose of private study or research.

- You may not further distribute the material or use it for any profit-making activity or commercial gain

- You may freely distribute the URL identifying the publication in the public portal 


\section{Accepted Manuscript}

Title: Study of influence of yeast cells treatment on sugarcane ethanol fermentation: Operating conditions and kinetics

Authors: Celina K. Yamakawa, Elmer Ccopa Rivera, Hyun Kwon, William E. Herrera Agudelo, Marcelo B.W. Saad, Jairo Leal, Carlos E.V. Rossell, Antonio Bonomi, Rubens Maciel Filho

PII:

DOI:

Reference: S1369-703X(19)30107-X https://doi.org/10.1016/j.bej.2019.03.022

To appear in: Biochemical Engineering Journal

Received date: $\quad 3$ August 2018

Revised date: $\quad 7$ March 2019

Accepted date: $\quad 25$ March 2019

Please cite this article as: Yamakawa CK, Rivera EC, Kwon H, Agudelo WEH, Saad MBW, Leal J, Rossell CEV, Bonomi A, Filho RM, Study of influence of yeast cells treatment on sugarcane ethanol fermentation: Operating conditions and kinetics, Biochemical Engineering Journal (2019), https://doi.org/10.1016/j.bej.2019.03.022

This is a PDF file of an unedited manuscript that has been accepted for publication. As a service to our customers we are providing this early version of the manuscript. The manuscript will undergo copyediting, typesetting, and review of the resulting proof before it is published in its final form. Please note that during the production process errors may be discovered which could affect the content, and all legal disclaimers that apply to the journal pertain. 


\section{Study of influence of yeast cells treatment on sugarcane ethanol fermentation: Operating conditions and kinetics}

Celina K. Yamakawa*1,2,3, Elmer Ccopa Rivera ${ }^{2,3,4}$, Hyun Kwon ${ }^{4}$, William E. Herrera Agudelo $^{2,3}$, Marcelo B.W. Saad ${ }^{3}$, Jairo Leal ${ }^{3}$, Carlos E.V. Rossell ${ }^{5}$, Antonio Bonomi ${ }^{2,3}$, Rubens Maciel Filho 2,3

${ }^{1}$ Novo Nordisk Foundation Center for Biosustainability, Technical University of Denmark, Kemitorvet, Building 220, 2800 Kongens Lyngby, Denmark

${ }^{2}$ School of Chemical Engineering, University of Campinas, P.O. Box 6066, 13081-970, Campinas, São Paulo, Brazil

${ }^{3}$ Laboratório Nacional de Ciência e Tecnologia do Bioetanol (CTBE), Centro Nacional de Pesquisa em Energia e Materiais (CNPEM), Caixa Postal 6192, CEP 13083-970, Campinas, São Paulo, Brazil

${ }^{4}$ Department of Engineering and Computer Science, Andrews University, Berrien Springs, MI , USA

${ }^{5}$ Interdisciplinary Center of Energy Planning (NIPE), University of Campinas, P. O. Box 6166, 13083-896, Campinas, São Paulo, Brazil

*celinayamakawa@biosustain.dtu.dk; celinayamakawa@gmail.com

Author contributions: Yamakawa, C. K., Agudelo, W. E. H., Saad, M. B. W., Leal, J. performed the experiments. Rivera, E. C. and Bonomi, A. designed the mechanistic model and computacional framework. Yamakawa, C. K. and Rivera, E. C. analysed the data and wrote the manuscript with support from Rossell, C. E. V. and Kwon, H. Maciel Filho, R., Rossell, C. E. V. and Bonomi, A. supervised the project. 


\title{
Graphical abstract
}

VHG ETHANOL FERMENTATION PROCESS WITH CELL RECYCLING:

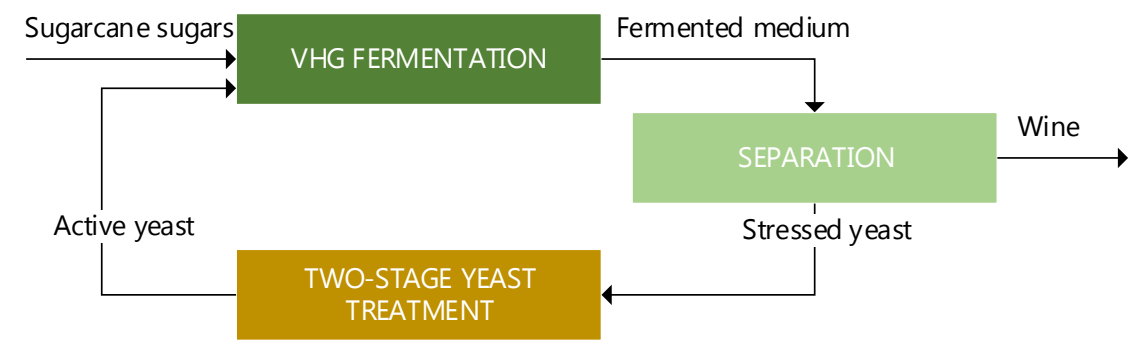

TWO-STAGE YEAST TREATMENT:

Stage 1: Cell washing, dispersion of yeast flocculation

Stage 2: Membrane restoration, recovery of cell viability and fermentation activity

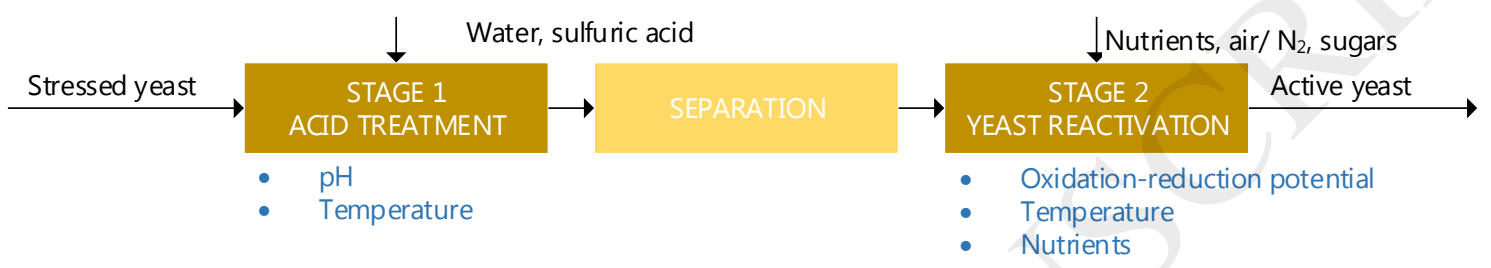

\section{Highlights}

- A two-stage yeast treatment is critical to maintain VHG fermentation with cell recycling

- The optimal conditions of acid treatment stage were $30^{\circ} \mathrm{C}, 2.65 \mathrm{pH}$ and $30 \mathrm{~min}$

- The highest cell viability was found at relatively low temperature and negative ORP

- Reaction rates were calculated for the yeast reactivation stage using a mechanistic model

- Real-time measurements yielded valuable information to modeling and optimization

\begin{abstract}
In this work, the effect of various operating parameters of the two-stage yeast treatment on the VHG fermentation performance was evaluated. First, a central
\end{abstract}


composite design was used to investigate the effects of temperature and $\mathrm{pH}$ on cell viability and flocculation dispersion in the acid treatment unit ( $1^{\text {st }}$ stage). Second, the effects of temperature, oxidation-reduction potential (ORP) and sugar concentration in the yeast reactivation $\left(2^{\text {nd }}\right.$ stage) on the performance parameters (productivity, ethanol yield and cell viability) of the VHG fermentation were evaluated through a full factorial design. The results indicated that the acid treatment around $2.65 \mathrm{pH}$ and temperature controlled at $30{ }^{\circ} \mathrm{C}$ for $30 \mathrm{~min}$ led to higher cell viability. The conditions of yeast reactivation stage that positively influenced the VHG fermentation performance were relatively low temperature and negative ORP. A mechanistic model quantitatively revealed the influence of the operating parameters studied on cell growth kinetics. The two-stage yeast treatment promoted cell viability recovery through the cell membrane recovery, which led to the maintenance or improvement the VHG fermentation performance.

Keywords: Yeast recycling; Kinetic modeling; Cell viability; Very-high-gravity fermentation; Ethanol

\section{Introduction}

The current sugarcane ethanol industry uses the ethanol fermentation process with cell recycling. In this technology, the sugarcane juice from the crushers is heated and concentrated or alternatively molasses is added to increase the sugars concentration. An initial culture of yeast Saccharomyces cerevisiae is produced at the beginning of the sugarcane harvesting season, and thereafter it is reused in a sequential fermentation. After the total consumption of sugars, the outlet fermented medium is centrifuged in nozzle separators. The light phase rich in ethanol is sent to the distillation unit in which the ethanol is recovered. The heavy phase with $60-70 \%$ of yeast is sent to a stirred tank where an acid treatment is performed. The acid treatment is used to promote 
dispersion of flocculated cells by reducing bacterial contamination and to remove volatile organic acids from yeast $[1,2]$. The acid treatment is an important part of cell recycling as it leads to a high cell density and thus shorter fermentation time to obtain high ethanol productivity [3].

An uniform suspension of yeast cells in the fermentation medium is essential for a high fermentation performance [4]. The flocculation occurs due to several factors, including the contact with gums produced by bacteria, or with flocculation inducing bacteria, or the direct contamination by flocculent yeast cells. This causes sedimentation of yeast cells at the bottom of reactors reducing mass transfer, which in turn inhibiting absorption of nutrients and antibiotics, and eventually reducing ethanol yield and quality. Flocculation also causes higher operating cost due to the loss of yeast cells in the nozzle separators.

The very-high-gravity (VHG) fermentation based on the patent WO2014078924A1 of CNPEM/CTBE [5] proposed the intensification of ethanol production to achieve high fermentation performance parameters. The main advantage of this technology is the increase of ethanol concentration up to $15 \%(\mathrm{v} / \mathrm{v})$ that consequently reduces the vinasse volume up to $5.4 \mathrm{~L}$ vinasse/ L ethanol. Current values vary from 12 to $15 \mathrm{~L}$ vinasse/ $\mathrm{L}$ ethanol. The volume reduction of vinasse enables a significant energy saving to achieve a final concentration of 1-2 L vinasse/ $\mathrm{L}$ ethanol, thus reducing the capital expenditure associated with its evaporation. Moreover, the high ethanol concentration results in the reduction of distillation cost and increase of productivity of up to $10.2 \mathrm{~g} /(\mathrm{L} \cdot \mathrm{h})$. Current productivities are $2.6 \mathrm{~g} /(\mathrm{L} \cdot \mathrm{h})$ for the fedbatch operation, and $5.5 \mathrm{~g} /(\mathrm{L} \cdot \mathrm{h})$ for the continuous operation. The main characteristics of the novel VHG technology are a well-defined temperature profile that considers a decrease of temperature as ethanol concentration rise, the application of micro-aeration 
when the ethanol concentration is approximately equal to $11 \%(\mathrm{v} / \mathrm{v})$ and the application of the two-stage yeast treatment to cell viability recovery, which lead to the maintenance of fermentation performance.

The oxidation-reduction potential (ORP) is a critical parameter used to monitor and regulate the metabolism of facultative microorganisms such as yeast in aerobic fermentation. It is suggested that the ORP can be very useful for the control of the micro-aeration applied to the fermentation stage and to the yeast treatment stage over the course of VHG fermentation. Lin et al. [6] applied the aeration strategy to control the ORP showing that $-150 \mathrm{mV}$ is the optimum value to achieve high productivity and yield in VHG fermentation. Kukec et al. [7] correlated yeast metabolic activity with ORP at different temperatures to optimize the wine fermentation process. According to these authors, above $+350 \mathrm{mV}$ the oxygen is toxic for the cells and leads to inhibition, and below $-200 \mathrm{mV}$ the oxygen is too low for yeast cells normal metabolic activity. In another study, Burmaster [8] has addressed the control of ORP in the fermentation medium in the range of $-250 \mathrm{mV}$ to $+50 \mathrm{mV}$ using hydrogen peroxide, ammonia and aeration as a strategy for the monitoring and control of the process. Temperature is another crucial operating parameter due to its influence on cell growth kinetics and consequently on the conversion of sugars to ethanol [9].

This study focused on the yeast treatment as a fundamental strategy on VHG fermentation. The effects of operating conditions of the two-stage yeast treatment on the performance parameters of the VHG fermentation were evaluated. This is also the first study to propose a mechanistic kinetic model of the yeast treatment.

\section{Material and methods}

In this study, the effects of various operating parameters of the two-stage yeast treatment on VHG fermentation performance were evaluated. A schematic 
representation of the process is shown in Fig. 1. First, the system under study was limited to the acid treatment unit $\left(1^{\text {st }}\right.$ stage $)$ where the effect of its operating parameters on cell viability and flocculation dispersion was studied through a central composite design (CCD). The optimal operating parameters of the acid treatment allowed to establish the conditions required for an actual environment with potential bacterial contamination. Second, the effects of temperature, oxidation-reduction potential and sugar concentration in the yeast reactivation stage $\left(2^{\text {nd }}\right.$ stage $)$ on the performance parameters (productivity, ethanol yield and cell viability) of the VHG fermentation were evaluated through a full factorial design (FFD). The evaluation of the yeast reactivation stage required the use of the optimized values of the operating parameters of the acid treatment stage. This is because this $2^{\text {nd }}$ stage was evaluated considering the entire VHG fermentation system under sterile conditions. Finally, the kinetic parameters for the fermentation stage and the yeast reactivation stage were estimated using mechanistic modeling for each condition defined by the FFD design.

\subsection{Acid treatment}

The effect of the operating parameters, temperature and $\mathrm{pH}$ on the cell viability and flocculation dispersion in the acid treatment ( $1^{\text {st }}$ stage $)$ was studied through a CCD design consisting of ten bench-scale experiments. These experiments were designed to reproduce the industrial operating conditions of yeast acid treatment including bacterial contamination by Lactobacillus fermentum. This study used a yeast / bacteria ratio that produced a high flocculation. This ratio was previously determined [10], and corresponds to $69.3 \mathrm{~g} / \mathrm{L}$ of yeast and $2.1 \mathrm{~g} / \mathrm{L}$ of bacteria on a dry basis.

\subsubsection{Microorganisms}

This study used the bacteria Lactobacillus fermentum ATCC 0559 obtained from the André Tosello Foundation (Campinas, SP, Brazil) and the yeast was provided by the 
Iracema sugarcane mill (Iracemápolis, SP, Brazil). The yeast in the form of a concentrated aqueous suspension (yeast cream) was collected from the acid treatment industrial tank. This solution at $\mathrm{pH}$ around 2.0 was stored at $4{ }^{\circ} \mathrm{C}$ until used. The $L$. fermentum was propagated anaerobically in batch mode using a 2 L Bioflo 115 bioreactor (New Brunswick, NJ, USA) at $35^{\circ} \mathrm{C}$, under agitation (100 rpm) and pH 6. The medium consisted of $10 \mathrm{~g} / \mathrm{L}$ triptone, $10 \mathrm{~g} / \mathrm{L}$ peptone, $5 \mathrm{~g} / \mathrm{L}$ yeast extract, $20 \mathrm{~g} / \mathrm{L}$ glucose, $1 \mathrm{~g} / \mathrm{L}$ Tween 80, $2 \mathrm{~g} / \mathrm{L}$ ammonium citrate, $0.6 \mathrm{~g} / \mathrm{L}$ urea, $2.28 \mathrm{~g} / \mathrm{L}$ sodium acetate, $3 \mathrm{~g} / \mathrm{L} \mathrm{KH}_{2} \mathrm{PO}_{4}, 0.1 \mathrm{~g} / \mathrm{L} \mathrm{MgSO}_{4} .7 \mathrm{H}_{2} \mathrm{O}$ and $0.05 \mathrm{MnSO}_{4} . \mathrm{H}_{2} \mathrm{O}$.

\subsubsection{Design of experiments for the acid treatment stage}

A CCD design shown in Table 1 was used to investigate the effects of temperature $(\mathrm{T})$ and $\mathrm{pH}$ on percentage of cell flocculation dispersion (PFD) and percentage of non-viable cell (PNC) in the acid treatment stage. Design of experiments such as CCD enabled simultaneous study of the operating parameters and their potential interactions [11]. The results were evaluated using Pareto charts, which indicated the more significant parameters. In this chart the magnitude of each bar, which was calculated by dividing the estimated effect by its standard error, represented a $t$-statistic. The magnitude of the bars greater than the critical $t$-value was considered statically significant at the $95 \%$ significance level.

All experiments were started by transferring the yeast cream to a bioreactor, followed by a $\mathrm{pH}$ adjustment to 5.0 with $\mathrm{NaOH}$ solution. The temperature was set according to each experiment defined by the CCD design. The first sample for each experiment was obtained when the temperature and $\mathrm{pH}$ reached stable values. Then, the bacteria were inoculated to the medium promoting an immediate flocculation. At this time, a second sample was withdrawn. After that, the acid treatment itself started with the $\mathrm{pH}$ adjustment using $\mathrm{H}_{2} \mathrm{SO}_{4}$ solution according to each experiment defined by the 
CCD design. Samples were withdrawn at 7, 15, 30, 60, 90, and $120 \mathrm{~min}$. All experiments were performed in a 2 L Bioflo 115 bioreactor (New Brunswick, NJ, USA) with a working volume of $600 \mathrm{~mL}$ under agitation (200 rpm).

\subsubsection{Analytical methods for the acid treatment stage}

The percentage of cell flocculation dispersion was calculated by using the Eq. 1. $\%$ of cell flocculation dispersion $(\mathrm{PFD})=-2.31 \times \eta+106$

where $\eta$ is viscosity in $\mathrm{cP}$.

The calibration of Eq. 1 was based on the two-points correlation. The first point was viscosity of $45.9 \mathrm{cP}$ were zero percentage of cell flocculation dispersion occurred. The second point was $2.6 \mathrm{cP}$ with $100 \%$ of flocculation after inoculation of the bacteria. The second viscosity was the minimum value after 120 minutes at $34{ }^{\circ} \mathrm{C}$ and $\mathrm{pH}$ 2.05. All viscosity measurements were performed via LVDV-III rheometer (Brookfield, Middleboro, USA) in $20 \mathrm{~mL}$ of a sample at $30^{\circ} \mathrm{C}$. A double check of cell flocculation dispersion was performed using an optical microscope (Eclipse CI-S, Nikon, Japan).

The determination of the percentage of non-viable cell (PNC) was based on the capacitance signals (Aber Instrument UK). The zero time in this determination was defined as the time before the induction of flocculation and after stabilization of temperature. The viable cell concentration measured at zero time was defined as $100 \%$ of viable cells. This measure was analyzed by staining the cells with methylene blue and counted using an optical microscope (Eclipse CI-S; Nikon, Japan) [12]. The capacitance signal is also known at zero time. Thus, the subtraction of each capacitance signal obtained during the acid treatment to the capacitance signal at time zero allowed the calculation of a percentage of variation over the course of the treatment. The variation 
of this percentage determined the PNC values, taking the measurement of viable cells at time zero as a calculation reference.

\subsection{Yeast reactivation}

The yeast reactivation is the second stage of a two-stage yeast treatment applied to a VHG fermentation process proposed by Rossell et al. [5], which is based on studies by Nonus and Miniac [13]. Unlike the acid treatment stage, the evaluation of this stage was performed considering the entire VHG fermentation system. Thus, this study also required the use of the optimized operating parameters of the acid treatment stage. The effect of the temperature, oxidation-reduction potential and sugars concentration on productivity, ethanol yield and cell viability was studied trough a FFD design consisting of eight experimental conditions (two sequential VHG fermentation cycles were performed for each experimental condition). The main aim of this stage was to maintain cell viability through the provision of nutrients after the acid treatment. The maintenance of viability is a critical condition in sugarcane mills to provide operating stability and efficiency of sugar conversion to ethanol for an entire harvest season. It is worthwhile mentioned that, the conditions of the VHG fermentation in which the study of the cellular reactivation stage was performed were different from those optimized conditions presented by Rossell et al. [5], in term of mode operation and temperature. The batch mode was used instead of the continuous mode, and also the micro-aeration was not applied to the fermentation, and also, a fixed fermentation temperature was used instead of an optimized temperature profile. As a consequence the yeast cells were exposed to stress barriers to highlight the effect of the application of the yeast reactivation stage performed in this study.

The substrate for the yeast reactivation and fermentation stages was composed by $79 \%(\mathrm{w} / \mathrm{w})$ from sugarcane juice and $21 \%(\mathrm{w} / \mathrm{w})$ from sugarcane molasses. The 
substrate concentration was $475 \mathrm{~g} / \mathrm{L}$ TSAI (total sugars as invert in which the original sucrose is equivalent to 0.95 of the reducing sugars formed (glucose and fructose) and glucose and fructose originally present). This stock concentration was then further diluted to $80 \mathrm{~g} / \mathrm{L}, 120$ or $160 \mathrm{~g} / \mathrm{L}$, and $194 \mathrm{~g} / \mathrm{L}$ to obtain the initial substrate concentrations for the propagation, yeast reactivation, and fermentation, respectively.

\subsubsection{Microorganism}

This study used an unclassified wild-type yeast Saccharomyces cerevisiae strain provided by the Faculty of Food Engineering/State University of Campinas (Campinas, SP, Brazil) and originally obtained from the Santa Adélia sugarcane mill. The stock culture was maintained in YPD $(10 \mathrm{~g} / \mathrm{L}$ yeast extract, $20 \mathrm{~g} / \mathrm{L}$ peptone and $20 \mathrm{~g} / \mathrm{L}$ dextrose) at $-80{ }^{\circ} \mathrm{C}$ with $30 \%(\mathrm{v} / \mathrm{v})$ glycerol. Wild-type yeast cells from Brazilian sugarcane mills responds to the stressful conditions of industrial fermentation such as high concentrations of ethanol, high osmotic pressure due to high sugars concentration and low $\mathrm{pH}$ values.

\subsubsection{Design of experiments to study the yeast reactivation stage}

The yeast reactivation experiments were performed under different conditions defined by the FFD design as shown in Table 2. For this analysis, the influences of temperature, oxidation-reduction potential (ORP) and sugars concentration in the yeast reactivation stage on the performance parameters (productivity, ethanol yield and cell viability) of the VHG fermentation were evaluated using a FFD design for three factors (operating parameters) at two levels. These experiments were performed in the $2 \mathrm{~L}$ Bioflo 115 bioreactor (New Brunswick, NJ, USA) at $600 \mathrm{rpm}$. The ORP was monitored using a redox electrode (Pt4805-DPAS-SC-K8S, Mettler Toledo, USA). The capacitance was also monitored using an annular capacitance probe (6532-52, Aber Instruments, UK). In the reactivation medium, sugarcane substrate and diammonium 
phosphate (fixed at $0.01 \mathrm{~g}$ of nitrogen per gram of cell, dry basis) were used to supply carbon, phosphorus and nitrogen for recovery of cell viability. The initial cell concentration was $30 \mathrm{~g} / \mathrm{L}$ (dry basis) in a medium with sugars concentration according to each experiment defined by the FFD design. The temperatures of the yeast reactivation used $\left(30^{\circ} \mathrm{C}\right.$ and $\left.34{ }^{\circ} \mathrm{C}\right)$ were those suitable for optimum yeast cells growth. Sugars concentrations of 120 and $160 \mathrm{~g} / \mathrm{L}$ were used to define the yeast reactivation time between 4 to $5 \mathrm{~h}$. The ORP was selected for the investigation of oxygen level rather than the dissolved oxygen (DO) due to ORP is a more sensitive measurement to monitor small changes of oxygen [15]. ORP represents the equilibration of oxidizing and reducing power (electrochemical or chemical). When the oxidizing power is greater than the reducing power, electrons are absorbed by oxidant resulting in an increase of ORP. In contrast, decrease of ORP means reduced environment. Based on that, this study used the total gas flow rate (air plus nitrogen) and the percentage of nitrogen (\% $\mathrm{N}_{2}$ ) in the total gas to adjust the ORP to the values defined by the FFD design, which are $-50 \mathrm{mV}$ and $+50 \mathrm{mV}$ corresponding to very low and low aeration, respectively. At a constant flow rate, the $\% \mathrm{~N}_{2}$ in the air/nitrogen mixture has an effect inversely proportional to the ORP. The flow rate was regulated when the $\% \mathrm{~N}_{2}$ adjustment was not sufficient to control the ORP. Under the eight experimental conditions defined by the FFD design, two sequential fermentation cycles were performed to obtain experimental data to investigate the effectiveness of the yeast reactivation stage on the VHG fermentation performance.

\subsubsection{Batch VHG fermentation}

A stock culture of yeast was activated in liquid YPD medium at $33{ }^{\circ} \mathrm{C}$ under agitation ( $250 \mathrm{rpm}$ ) for $24 \mathrm{~h}$ on an Innova 44 orbital shaker (New Brunswick, NJ, USA). The cells were recovered using a Beckman Avanti J-26 XP centrifuge (JLA-10.500 
rotor, $6675 \times \mathrm{g}, 4^{\circ} \mathrm{C}$ and $15 \mathrm{~min}$ ). Then, the cells were incubated in $1 \mathrm{~L}$ shake flask with $200 \mathrm{~mL}$ of a new semi-synthetic liquid medium at $33{ }^{\circ} \mathrm{C}$ for $24 \mathrm{~h}$ on an Innova 44 orbital shaker (New Brunswick, NJ, USA). The semi-synthetic medium consisted of $2.30 \mathrm{~g} / \mathrm{L}$ urea, $6.60 \mathrm{~g} / \mathrm{L} \mathrm{K} \mathrm{K}_{2} \mathrm{SO}_{4}, 3.0 \mathrm{~g} / \mathrm{L} \mathrm{KH}_{2} \mathrm{PO}_{4}, 0.50 \mathrm{~g} / \mathrm{L} \mathrm{MgSO}_{4} \cdot 7 \mathrm{H}_{2} \mathrm{O}, 1.0 \mathrm{~g} / \mathrm{L}$ $\mathrm{CaCl}_{2} \cdot 2 \mathrm{H}_{2} \mathrm{O}, 5.0 \mathrm{~g} / \mathrm{L}$ yeast extract, $25.44 \mathrm{mg} / \mathrm{L}$ trace elements and $80.0 \mathrm{~g} / \mathrm{L}$ TSAI. After the inoculation period was complete, the cells were recovered as previously described. The cells were diluted with sterilized potable water, and this suspension was inoculated in a 5 L Bioflo 115 bioreactor (New Brunswick, NJ, USA). The medium for the cell propagation was similar to the semi-synthetic medium described above. The propagation was conducted under aerobic conditions at $33{ }^{\circ} \mathrm{C}$ for $24 \mathrm{~h}$. After all sugars were consumed, to recover cells, the fermented medium was centrifuged using a Beckman Avanti J-26XP centrifuge (JLA-9.1000 rotor, $13261 \times \mathrm{g}, 20{ }^{\circ} \mathrm{C}, 20 \mathrm{~min}$ ). The cells were re-suspended with sterilized potable water and kept refrigerated at $4{ }^{\circ} \mathrm{C}$ until inoculation for further fermentations. VHG fermentations were performed soon after yeast reactivation stage using the same bioreactor setup as described in Section 2.2.2. The oxidation-reduction potential and capacitance were also monitored. Two sequential fermentation cycles were performed for each experimental condition defined by the FFD design shown in Table 2. All stages described in Fig. 1 are conducted for each cycle. A fermentation cycle was composed by a VHG fermentation stage, followed by centrifugation to recover the stressed yeast cells, and then, the acid treatment was applied. After a new centrifugation the yeast reactivation stage was performed. For the Cycle 1, the initial cell concentration was $20 \mathrm{~g} / \mathrm{L}$ (dry basis). The VHG fermentation was conducted in batch mode at $33{ }^{\circ} \mathrm{C}$ under agitation $(200 \mathrm{rpm})$ with substrate concentration of $194 \mathrm{~g} / \mathrm{L}$. The fermentation time for each cycle varied from 18 to $24 \mathrm{~h}$. After fermentation was complete, the cells were recovered using a Beckman Avanti J- 
26XP centrifuge (JLA-9.1000 rotor, $13261 \times \mathrm{g}, 20^{\circ} \mathrm{C}, 20 \mathrm{~min}$ ). The cells were resuspended with sterilized potable water, and then, they were transferred back to the bioreactor vessel where the two-stage yeast treatment was performed. Acid treatment was performed under optimal conditions for $\mathrm{pH}$ and temperature as determined by the results from the CCD design described in Results and discussion section. Sulfuric acid (2 M) was added on the cells through a silicon septum until a $\mathrm{pH}$ of.2.5 was reached (slightly lower than the optimal value of 2.65 to induce stress). The acid treatment conditions were $30{ }^{\circ} \mathrm{C}, 0.2 \mathrm{~L} / \mathrm{min}$ of air (positive pressure to avoid contamination) and $600 \mathrm{rpm}$ for $30 \mathrm{~min}$. This acid cell suspension was centrifuged again as previously described. Then the cells removed from centrifuge were re-suspended with cooled reactivation medium. This cell suspension was transferred back to the bioreactor vessel for the yeast reactivation (second stage), followed by a new VHG fermentation, which started the Cycle 2.

\subsubsection{Analytical methods for the yeast reactivation stage}

The sucrose, glucose plus fructose, glycerol, and ethanol measurements from the yeast reactivation stage were analyzed in a platinum diamond attenuated total reflectance (ATR platinum T Diamond 1 Refl \#263C3643) single reflection cell, mounted in a mid-infrared Bruker Alpha Fourier transform infrared (FT-IR) spectrometer (Bruker Optics Inc., USA). A historical database of samples were used to calibrate the spectrometer using HPLC as the primary analyses. Details are provided elsewhere [9].

The sucrose, glucose, fructose, ethanol, glycerol and acids measurements were also taken via HPLC to check the accuracy of mid-infrared spectroscopy. However, HPLC was applied only for the first and last samples during fermentation for validation purposes of the ethanol yield calculation. Sucrose, glucose and fructose measurements 
were analyzed by Agilent 1260 infinity HPLC system whereas the ethanol, glycerol as well as lactic, acetic and succinic acids were analyzed by Dionex Ultimate 3000 HPLC system. Sucrose, glucose and fructose were separated in a Bio-Rad Aminex ${ }^{\circledR}$ HPX-87P column, $300 \mathrm{~mm} \times 7.8 \mathrm{~mm}$ (at $60^{\circ} \mathrm{C}$; deionized water as the mobile phase at a flow rate of $0.5 \mathrm{~mL} / \mathrm{min}$ ) and detected with refractive index detector. Ethanol, glycerol as well as succinic, acetic and lactic acids were separated in a Bio-Rad Aminex ${ }^{\circledR}$ column HPX$87 \mathrm{H}, 300 \mathrm{~mm} \times 7.8 \mathrm{~mm}\left(\right.$ at $50{ }^{\circ} \mathrm{C} ; 5.0 \mathrm{mM} \mathrm{H}_{2} \mathrm{SO}_{4}$ as the mobile phase at a flow rate of $0.5 \mathrm{~mL} / \mathrm{min}$ ) and detected with a Shodex RI-101 refractive index detector. The total cell concentration $\left(X_{t o t}\right)$ was determined gravimetrically after centrifuging, washing two times with deionized water and drying at $80{ }^{\circ} \mathrm{C}$ until a constant weight was obtained in an analytical balance. The viable cell concentration $\left(X_{v}\right)$ was quantitatively determined by multiplying $X_{t o t}$ and the percentage of viable cells, which was determined by the counting procedure describes in Section 2.1.3. The $X_{v}$ was also calculated by using Eq. 2 for the analysis at real-time and for comparison with those measurements obtained by the counting procedure. An additional check was performed by colonies growing on YPD agar plates. The Eq. 2 shows a correlation between $X_{v}$ measurements determined by counting procedure (from a historical database of $X_{v}$ measurements) and capacitance signals. This correlation valid in the range of 15 to $30 \mathrm{~g} / \mathrm{L}$ can be used to quantitatively determine $X_{v}$ with high accuracy $\left(\mathrm{R}^{2}=0.981\right)$.

$X_{v}=-7.3814+1.2862 \times$ capacitance

where capacitance is in $\mathrm{pF} / \mathrm{cm}$.

\subsubsection{Mathematical modeling}

A mechanistic model that describes the kinetics of the concentrations of viable cell, $X_{v}(\mathrm{~g} / \mathrm{L})$, substrate, $S(\mathrm{~g} / \mathrm{L})$, and ethanol, $P(\mathrm{~g} / \mathrm{L})$, in terms of three ordinary 
differential equations, i.e., Eqs. 3-5, was applied for the yeast reactivation and fermentation stages:

$$
\begin{aligned}
& \frac{d X_{v}}{d t}=r_{x} \\
& \frac{d S}{d t}=-r_{s} \\
& \frac{d P}{d t}=r_{p}
\end{aligned}
$$

where $r_{x}, r_{s}$ and $r_{p}$ represent the viable cell, substrate consumption and ethanol production reaction rates, respectively $(\mathrm{g} /(\mathrm{L} \cdot \mathrm{h}))$.

During the yeast reactivation and fermentation stages, the cells are exposed to stress barriers, including osmotic stress due to high substrate concentration, high cell densities and ethanol stress. Thus, to simulate the physiological state of yeast cells during these stages, terms for the cell substrate and ethanol inhibitions were considered in the viable-cell growth rate, $r_{x}$, in Eq. 6 .

$$
r_{x}=\mu_{\max } \frac{S}{K_{s}+S} \exp \left(-K_{i} S\right)\left(1-\frac{P}{P_{\max }}\right)^{n}\left(1-\frac{X_{v}}{X_{\max }}\right)^{m} X_{v}
$$

where $\mu_{\max }$ is the maximum specific growth rate $\left(\mathrm{h}^{-1}\right), K_{s}$ is the substrate saturation constant $(\mathrm{g} / \mathrm{L}), K_{i}$ is the substrate inhibition parameter $(\mathrm{g} / \mathrm{L}), X_{\max }$ is the cell concentration when cell growth ceases $(\mathrm{g} / \mathrm{L}), P_{\max }$ is the ethanol concentration when cell growth ceases $(\mathrm{g} / \mathrm{L})$ and $m$ and $n$ are parameters related to cellular and product inhibitions, respectively.

The ethanol production rate, $r_{p}$, is consistent with the growth and non-growth associated product model proposed by Luedeking and Piret [16] and is represented in Eq. 7. 
$r_{p}=Y_{p / x} r_{x}+m_{p} X_{v}$

where $Y_{p / x}$ denotes the Luedeking-Piret growth-associated constant $(\mathrm{g} / \mathrm{g})$ and $m_{p}$ denotes the Luedeking-Piret non-growth-associated constant $(g /(g \cdot h))$.

The substrate consumption rate, $r_{s}$, is given by Eq. 8, by considering that the substrate consumed is related to yeast cells growth and other processes requiring energy.

$r_{s}=r_{x} / Y_{x}+m_{s} X_{v}$

where $Y_{x}$ and $m_{s}$ are the cell yield $(\mathrm{g} / \mathrm{g})$ and maintenance parameter $(\mathrm{g} /(\mathrm{g} \cdot \mathrm{h}))$, respectively.

The kinetic model was formed using Eqs. 3-8, which containing eleven kinetic parameters. In this study, the statistically significant parameters $\mu_{\max }, X_{\max }, P_{\max }, Y_{p / x}, Y_{x}$ and $k_{i}$ [9] were estimated for each experiment defined by the FFD shown in Table 2. The remaining parameters were fixed as follows [17]: $K_{s}=4.1 \mathrm{~g} / \mathrm{L}, m_{p} 0.1 \mathrm{~g} /(\mathrm{g} \cdot \mathrm{h}), m_{s}=$ $0.2 \mathrm{~g} /(\mathrm{g} \cdot \mathrm{h}), m=1.0$ and $n=1.5$. A hybrid optimization algorithm as proposed by Rivera et al. [9] is adopted to solve a nonlinear optimization problem to estimate the kinetic parameters.

\subsection{Fermentation performance parameters}

The ethanol yield and the volumetric productivity were calculated for the yeast reactivation stage and fermentation stage. Details of determination of fermentation performance parameters are provided elsewhere [9].

\section{Results and Discussion}

\subsection{Acid treatment study results}

Fig. 2A shows the optical microscopy images of the cells from the yeast cream collected from an ethanol distillery. The images also show the behavior of yeast flocculation by L. fermentum with flocs of 16 yeast cells intertwined with bacteria (Fig. 
2B) as well as their effective dispersion by the acid treatment (Fig. 2C). In this study, a model-based approach was used to better understand the phenomena involved in these observations.

The results of the percentage of cell flocculation dispersion and the percentage of non-viable cells observed at $60 \mathrm{~min}$ for each experiment defined by the CCD design are shown in Table 1 . The mean of the initial viscosity for all experiments was $45.9 \pm$ $1.4 \mathrm{cP}$. The acid treatment was highly effective for Experiments 1, 2, 5, 7 and 8, where the percentage of cell flocculation dispersion was greater than $88 \%$. In addition, the acid treatment caused the highest non-viable cell of $14.1 \%$ in Experiment 5, which demonstrated that at a $\mathrm{pH}$ as low as 1.8 , it could cause yeast cells damage. The flocculation dispersion occurred with $30 \mathrm{~min}$ of acid treatment and remained practically constant until 120 min (data not shown).

The Figs. 3A and 3B show the Pareto charts obtained from CCD design for responses percentage of cell flocculation dispersion and percentage of non-viable cells, respectively. According to the estimated effects, the linear effect of $\mathrm{pH}$ was considered statistically significant for the percentage of cell flocculation dispersion. In addition, the linear and quadratic effects of $\mathrm{pH}$, linear effect of temperature as well as the interaction effect of $\mathrm{pH}$ and temperature were considered statistically significant for the percentage of non-viable cells. According to the contour plot in Fig. 4A, lower $\mathrm{pH}$ values resulted in higher percentage of cell flocculation dispersion. Nevertheless, $\mathrm{pH}$ values as low as 1.0 and 1.5 can severely affect the growth of the rough yeast strain [18]. A non-linear interaction between $\mathrm{pH}$ and temperature can be also corroborated by the contour plot for the percentage of cell flocculation dispersion. The contour plot for the percentage of non-viable cells (Fig. 4B) indicated that value below $5.0 \%$ was obtained at $\mathrm{pH}$ around 
the central point $(\mathrm{pH} 2.65)$ and the temperature range from 24 to $30^{\circ} \mathrm{C}$. Temperatures below and above this range led to an increase in the percentage of non-viable cells.

The results aforementioned indicated that the industrial operation conditions of acid treatment of yeast cells can be optimized in terms of cell viability considering a reduction of the sulfuric acid to bring the $\mathrm{pH}$ to 2.65 (instead of the current value of 2.0 $\mathrm{pH}$ ), reduction of the treatment time to $30 \mathrm{~min}$ (instead of the current values that vary from 1 to $2 \mathrm{~h}$ ), and temperature controlled at $30^{\circ} \mathrm{C}$.

\subsection{VHG fermentation with two-stage yeast treatment results}

Fig. 5 shows the comparison between the relative logarithmic cell total concentration, $\ln X_{t o t} / X_{0}$, and the relative logarithmic viable cell concentration, $\ln X_{v} / X_{0}$, in the yeast reactivation stage for the first (Figs. 5A) and second (Figs. 5C) cycles of Experiment 1 and in the fermentation stage for the first (Figs. 5B) and second (Figs. 5D) cycles of the same experiment. $X_{0}$ corresponded to the initial cell concentration at zero time. The comparative analysis of Experiments 2 to 8 gave equivalent results (data not shown). Eq. 2 is used to calculate $X_{v}$ in Fig. 5. These results reported that the specific growth rate of viable cells was higher than the specific growth rate of total cells during the yeast reactivation stage whereas the opposite can be observed during the fermentation stage. Analytical method used to monitor the cell viability in real-time was by capacitance induction by a radio-frequency electrical field; cells with a damaged membrane do not interfere with the signal and the cells do not become polarized [19]. Thus, a higher specific growth rate of viable cells during the yeast reactivation stage could be mainly because of the cell membrane recovery rather than cell growth. On the other hand, a lower specific growth rate of viable cells observed during the fermentation stage could be due to cell membrane damage in the presence of high ethanol content. These real-time observations of the specific growth rate of viable cells explore the cell 
metabolic activity in the yeast reactivation stage, supporting the study of the effectiveness of the two-stage yeast treatment on VHG fermentation performance.

The Table 3 and 4 show the performance parameters for the yeast reactivation stage (first and second cycles) and fermentation stage (first and second cycles), respectively, for each experiment defined by the FFD design shown in Table 2. These results reported that the highest and lowest values for the performance parameters correspond to Experiments $1\left(30{ }^{\circ} \mathrm{C},-50 \mathrm{mV}, 120 \mathrm{~g} / \mathrm{L}\right.$ of TSAI $)$ and $4\left(34{ }^{\circ} \mathrm{C},+50 \mathrm{mV}\right.$, $120 \mathrm{~g} / \mathrm{L}$ of TSAI), respectively. In fact, the productivity and ethanol yield of Experiment 1 in the fermentation stage were higher than those obtained for the other experiments as shown in Table 4. The favorable operating conditions of the yeast reactivation stage of Experiment 1 could have led to this result. The percentage of cell viability was between 62 and $84 \%$ for the yeast reactivation stage and 65 and $82 \%$ for the fermentation stage. In general, for each experiment the percentage of cell viability was similar for the first and second cycles of the fermentation stage. These results demonstrated that the twostage yeast treatment allowed to maintain cell viability whereas the VHG fermentation occurs at high concentrations of ethanol (up to $120 \mathrm{~g} / \mathrm{L}$ ). The comparison of Experiment $1\left(30{ }^{\circ} \mathrm{C},-50 \mathrm{mV}, 120 \mathrm{~g} / \mathrm{L}\right.$ of TSAI $)$ and Experiment $2\left(34{ }^{\circ} \mathrm{C},-50 \mathrm{mV}, 120 \mathrm{~g} / \mathrm{L}\right.$ of TSAI) shows that the increase of temperature caused a decrease of cell viability of $12 \%$ (considering a mean value of first and second cycles). In addition, the comparison of Experiment 1 and Experiment $3\left(30{ }^{\circ} \mathrm{C},+50 \mathrm{mV}, 120 \mathrm{~g} / \mathrm{L}\right.$ of TSAI) shows that the effect of switching the oxidation-reduction potential (ORP) from a negative to a positive value by increasing aeration, causes a decrease in cell viability of $16 \%$. A decrease in cell viability up to $12 \%$ is also caused by increasing sugars concentration, as observed when comparing Experiment 1 and Experiment $5\left(30{ }^{\circ} \mathrm{C},-50 \mathrm{mV}, 160 \mathrm{~g} / \mathrm{L}\right.$ of TSAI). These results suggest that yeast cells prefer a minimal aeration for cell membrane formation 
through sterols synthesis. The productivities obtained (between 3.91 and $5.91 \mathrm{~g} /(\mathrm{L} \cdot \mathrm{h})$ ) are higher compared to the typical industrial values working in fed-batch mode (2.6 $\mathrm{g} /(\mathrm{L} \cdot \mathrm{h}))$ and equivalent to that observed in distilleries working in continuous mode $(5.5$ $\mathrm{g} /(\mathrm{L} \cdot \mathrm{h}))[14]$. However, greater productivities and fermentative yields can be achieved in VHG fermentation technology by applying multistage bioreactors with a well-defined temperature profile, micro-aeration and fed-batch or continuous operation strategies as demonstrated in previous studies [5, 14].

The Fig. 6 shows the ORP during the yeast reactivation stage, followed by the fermentation stage for the first cycle of Experiment 1. The ORP was controlled around $50 \mathrm{mV}$ in the yeast reactivation stage by regulating $\% \mathrm{~N}_{2}$ injection and total gas flow rate (air plus $\mathrm{N}_{2}$ ) whereas the fermentation stage was conducted at anaerobic condition. The profile of the ORP during the fermentation stage corresponds mainly to an environment with a high $r_{p}$; the range of $-50 \mathrm{mV}$ to $-200 \mathrm{mV}$ shown agrees with previous studies [14, 20]. A decrease of values of ORP was also observed until the total consumption of sugars. Liu et al. [20] reported an increase in ORP after $25 \mathrm{~h}$ of fermentation as a response to the lysis of cells and the corresponding release of oxidative metabolites into the fermentation medium. Taking into consideration those results, in a previous study Yamakawa et al. [14] supplied air after 8 hours of fermentation to avoid cells damage and to minimize residual sugars. The high productivities obtained demonstrated that strategy was really effective to sustain VHG fermentation. The present study broaden and deepen the effect of the ORP on the VHG fermentation performance. Therefore, the ORP, in addition to the temperature and the requirement of sugars should also be considered a critical parameter for the design and selection of equipment, thus optimizing operational cost. 
The Fig. 7A shows the measured concentrations of sucrose, glucose, fructose, $X_{t o t}, X_{v}$ and $P$ for the second cycle of Experiment 1 for the fermentation stage. The results illustrated that the fructose was consumed within $16 \mathrm{~h}$, whereas the glucose was almost completely consumed within $12 \mathrm{~h}$. The ethanol started with a concentration of about $40 \mathrm{~g} / \mathrm{L}$ coming from the yeast reactivation stage and then increased to $120 \mathrm{~g} / \mathrm{L}$ by conversion of sugars provided. The cell growth rate was minimal as desired and neither an inhibitory tendency nor cell death was shown. The measured concentrations of acetic (Ac), lactic $(\mathrm{La})$ and succinic $(\mathrm{Su})$ acids, and glycerol in the second cycle of Experiment 1 are shown in Figs. 7B. These by-products were produced in smaller quantities, however they could impair the fermentation performance. Rossell et al. [5] proposed a well-defined temperature profile and micro-aeration to minimize their production. The concentration profiles of Experiment 1 illustrated in the Fig 7 and the equivalent results for Experiments 2 to 8 in the FFD design are used for the estimation of kinetic parameters using the mechanistic model proposed. These profiles were obtained through analytical techniques, including real-time monitoring techniques based on FT-IR and capacitance signals. The combination of this data source and mechanistic modeling could lead to an increased understanding of fermentation on a physiological level [21].

For screening purposes, the responses obtained for the fermentation performance parameters were evaluated by using the Pareto chart, considering a $95 \%$ significance level. Fig. 8A shows the Pareto chart obtained from the FFD design for the cell viability response in the second cycle of fermentation. According to the estimated effects, ORP and temperature, as well as the interaction effects between ORP and temperature were considered statistically significant for cell viability. The analysis at this point of the process clearly showed the positive effect of the yeast reactivation stage on the VHG fermentation, which is characterized by high concentrations of sugars and ethanol. 
Contour plot shown in Fig. 8B shows that the maximum viability corresponded to relatively lower temperature and negative ORP. Negative values of ORP were found for wild yeast throughout the ethanol fermentation [22]. The effects of oxidation-reduction potential, temperature and sugars concentration on productivity and ethanol yield responses in the second cycle of fermentation were not considered statistically significant at $95 \%$ significance level.

\subsection{Kinetic study results}

A series of VHG fermentation experiments were performed using different conditions of oxidation-reduction potential, temperature and sugars concentration defined by the FFD design, as shown in Table 2. The results of these experiments were used to perform an optimization problem to estimate the parameters $\mu_{\max }, X_{\max }, P_{\max }$, $Y_{p / x}, Y_{x}$ and $k_{i}$ of the model described by Eqs. 3-8. A set of optimal values of these parameters was generated for the yeast reactivation stage and fermentation stage for each condition. Table 5 shows the optimal values of the parameters. This information clearly demonstrated the influence of oxidation-reduction potential, temperature and sugars concentration on the kinetic parameters. For most conditions, the values of $\mu_{\max }$ are slightly higher in the yeast reactivation stage to those for the fermentation stage, which demonstrated that the metabolism and multiplication are slightly less inhibited in the yeast reactivation stage. The highest and lowest values of $\mu_{\max }$ in the fermentation stage corresponded to Experiments 1 and 4, respectively, as shown in Table 5. The Experiments 1 and 4 also showed the highest and lowest values, respectively, for the fermentation performance parameters, as shown in Tables 3 and 4. A noticeable difference was also shown for the values calculated for $X_{\max }$ and $P_{\max }$ in the yeast reactivation stage when compared with those for the fermentation stage, suggesting that tolerance to cell and ethanol concentrations was higher in the yeast reactivation stage 
leading to higher $\mu_{\max }$. In addition, yield of ethanol per unit viable-cell, $Y_{p / x}$, exhibited lower values in the yeast reactivation stage than those shown for the fermentation stage. Although this condition was sought in the reactivation stage, i.e., minimize the ethanol formation and increase cell viability, the yeast $S$. cerevisiae as facultative anaerobic produced ethanol under aerobic conditions and high substrate concentration. Consequently, values of viable-cell yield, $Y_{x}$, were slightly only higher than those shown for the fermentation stage because part of the substrate was deviated to ethanol pathway. The values of $k_{i}$ showed a substrate inhibition in the yeast reactivation stage, which was slightly higher than those observed in the fermentation stage.

The computed profiles (from the model described by Eqs. 3-8) of viable cells, sugars and ethanol concentrations for the yeast reactivation stage and fermentation stage for the first and second cycles of Experiment 1 are shown in Fig. 8. The measured concentrations used for the parameter estimation are also shown in this figure for comparison. The results show that the model effectively tracks the desired trajectory of the measured data for the two fermentation cycles considered. The model predictions under the current condition were particularly accurate, as determined by the Residual Standard Deviation (RSD (\%)). These results showed that the viable cells increased exponentially at the beginning and reached a stationary phase after $4 \mathrm{~h}$ in the reactivation stage for the two cycles considered (Fig. 9A and 9C). The viable cells had an exponential growth rate higher than that shown in the fermentation stage (Fig. 9B and 9D). A nutrient supplementation and aeration strategy was used to achieve that viable-cell growth rate. The maintenance of the biological membranes integrity under these conditions avoided the stresses upon them by the formation of ethanol, glycerol and weak acids, such as acetic and lactic acid [23, 24]. The reactivation stage of the yeast had a maximum time of $5 \mathrm{~h}$, as established in previous studies $[9,14]$. The ethanol 
fermentation times for the first and second cycles were 18 and $21 \mathrm{~h}$, respectively, corresponding to the complete sugars depletion. The maximum concentration of ethanol for the first and second cycles of the fermentation stage were $122 \mathrm{~g} / \mathrm{L}$ and $130 \mathrm{~g} / \mathrm{L}$, respectively, which were consistent with typical VHG fermentations as reported in the review by Puligundla et al. [25]. It should be noted that after the yeast reactivation stage (Fig. 9A and Fig. 9C) where there was conversion of sugars into ethanol even under aerobic conditions (Crabtree effect), the sugars to start the fermentation stage were fed directly to the reactivation medium without prior centrifugation. Thus, those initial concentrations of ethanol of 28 and $30 \mathrm{~g} / \mathrm{L}$ in the fermentation stages (Fig. 9B and Fig. 9D) came from their corresponding reactivation stages. The purpose of this procedure was to keep the concept of an industrial plant where the addition of another centrifugation step would rise the operational cost.

The application of VHG fermentation with two-stage yeast treatment will introduce new challenges for ethanol processing plants that are highly dependent on proper viable-cell growth in a non-sterile environment. The knowledge of the kinetic mechanism of yeast cells in the different stages of the VHG fermentation should contribute to the success of the implementation of this novel technology.

\section{Conclusions}

This study demonstrated that the cell viability in the acid treatment is significantly influenced by the $\mathrm{pH}$, while the effect of temperature was found to be less significant for this stage at $95 \%$ significance level. The adequate control of the operating parameters of the yeast reactivation stage such as temperature and oxidationreduction potential favored the fermentation performance. The use of real-time measurements obtained using techniques based on FT-IR and capacitance signals demonstrated that this information was useful for the calibration of a mechanistic 
model. These techniques require frequent updating of calibration curves through primary analysis such as HPLC and cell counting procedure due to the variability of feedstock quality and cellular stress during the sugarcane harvesting season. Viable-cell growth in the yeast reactivation stage can be predicted using the mechanistic model under different operating conditions.

\section{Acknowledgements}

The authors acknowledge FAPESP (process numbers 2011/51902-9, 2015/20630-4 and 2017/23335-9) and Brazilian Bioethanol Science and Technology Laboratory/Brazilian Center of Research in Energy and Materials (CTBE/CNPEM) for their financial support, assistance regarding the use of facilities and sharing expertise. A special thanks to André Alves from CTBE/CNPEM in the HPLC analysis. The authors also thanks to Prof. Francisco Maugeri Filho from the University of Campinas who provided the yeast strain, Prof. Pilar Rodriguez de Massaguer from the André Tosello Foundation who provided the bacteria strain and Iracema sugarcane mill who provided the yeast cream. 


\section{References}

[1] C.E.V. Rossell, C.K. Yamakawa, E.C. Rivera, J. Nolasco Junior, Ethanol Production, in: Rein P. (Ed.), Cane Sugar Engineering, Bartens, Berlin, 2016, pp. $655-711$

[2] M.L. Lopes, S.C. de L. Paulillo, A. Godoy, R.A. Cherubin, M.S. Lorenzi, F.H.C. Giometti, C.D. Bernardino, H.B. de Amorim Neto, H.V. de Amorim, Ethanol production in Brazil: a bridge between science and industry, Brazilian J. Microbiol. 47 (2016) 64-76. doi:10.1016/j.bjm.2016.10.003.

[3] V. Raghavendran, T.P. Basso, J.B. da Silva, L.C. Basso, A.K. Gombert, A simple scaled down system to mimic the industrial production of first generation fuel ethanol in Brazil, Antonie van Leeuwenhoek, Int. J. Gen. Mol. Microbiol. 110 (2017) 971-983. doi:10.1007/s10482-017-0868-9.

[4] K.M. Ludwig, P. Oliva-Neto, D.F. De Angelis, Quantificação da floculação de Saccharomyces cerevisiae por bactérias contaminantes da fermentação alcoólica, Ciência e Tecnol. Aliment. 21 (2001) 63-66. doi:10.1590/S010120612001000100014.

[5] C.E.V. Rossell, J. Nolasco Junior, C.K. Yamakawa, Processo e equipamento para fermentação continua multiestágio com recuperação, reativação, e reciclo de fermento para obtenção de vinhos com alto teor alcoólico, Patent WO2014078924A1, 2012.

[6] Y.H. Lin, W.S. Chien, K.J. Duan, Correlations between reduction-oxidation potential profiles and growth patterns of Saccharomyces cerevisiae during veryhigh-gravity fermentation, Process Biochem. $45 \quad$ (2010) 765-770. doi:10.1016/j.procbio.2010.01.018. 
[7] A. Kukec, M. Berovic, S. Celan, M. Wondra, The role of on-line redox potential measurement in Sauvignon blanc fermentation, Food Technol. Biotechnol. 40 (2002) 49-55. http://www.scopus.com/inward/record.url?eid=2-s2.00036004401\&partnerID=40\&md5=e923fa499d26e3a99c0e276c2637bdfe.

[8] B.M. Burmaster, Ethanol fermentation using oxidation reduction potential. Patent US7078201B2, 2006.

[9] E.C. Rivera, C.K. Yamakawa, M.B.W. Saad, D.I.P. Atala, W.B. Ambrosio, A. Bonomi, J. Junior, C.E.V. Rossell, Effect of temperature on sugarcane ethanol fermentation: Kinetic modeling and validation under very-high-gravity fermentation conditions, Biochem. Eng. J. $119 \quad$ (2017) 42-51. doi:10.1016/j.bej.2016.12.002.

[10] C.K. Yamakawa, Evaluation of alcoholic fermentation with cell recycling of cellulosic hydrolysate from sugarcane bagasse in an integrated and stand-alone unit. Ph.D. Thesis, University of Campinas, Brazil, 2016, (in Portuguese).

[11] D.C. Montgomery, Design and Analysis of Experiments, John Wiley \& Sons, Hoboken, NJ, 2013.

[12] S.S. Lee, F.M. Robinson, H.Y. Wang, Rapid Determination of yeast viability. Biotechnology and Bioengineering Symp. 11 (1981) 641-649.

[13] M. Nonus, M. De Miniac, Gain de productivité d'éthanol en fermentation alcoolique des produits de sucrerie (mélasses et égoûts). Ind. Aliment. Agric. 102 (1985) 971-985.

[14] C.K. Yamakawa, D.I.P. Atala, W.B. Ambrosio, J. Nolasco Junior, C.E.V. Rossell, Assessment of VHG (very-high-gravity) ethanol fermentation in continuous multistage with cell recovery, reactivation and recycling using a blend of juice and molasses from sugarcane as raw material, Sugar Ind. 4 (2017) 212-213. 
[15] D.J. Killeen, R. Boulton, A. Knoesen, Advanced monitoring and control of redox potential in wine fermentation, Am. J. Enol. Vitic. (2018) ajev.2018.17063. doi:10.5344/ajev.2018.17063.

[16] R. Luedeking, E.L. Piret, A kinetic study of the lactic acid fermentation. Batch process at controlled pH, Biotechnol. Bioeng. 1 (1959) 393-412.

[17] D.I.P. Atala, A.C. Costa, R. Maciel Filho, Kinetics of ethanol fermentation with high biomass concentration considering the effect of temperature. Appl. Biochem. Biotechnol., 91-93 (2001) 353-365.

[18] V.R. Reis, A.P.G Bassi, J.C.G. Silva, S.R. Ceccato-Antonini, Characteristics of Saccharomyces cerevisiae yeasts exhibiting rough colonies and pseudohyphal morphology with respect to alcoholic fermentation. Braz. J. Microbiol., 44 (2013) 1121-1131. doi:10.1590/S1517-83822014005000020.

[19] J. Carvell, K. Turner, New applications and methods utilizing radio-frequency impedance measurements for improving yeast management. MBAA, 40 (2003) $30-38$.

[20] C.G. Liu, C. Xue, Y.H. Lin, F.W. Bai, Redox potential control and applications in microaerobic and anaerobic fermentations. Biotechnol. Adv. 31 (2013) 257-65. doi:10.1016/j.biotechadv.2012.11.005.

[21] A. Golabgir, C. Herwing, Combining mechanistic modeling and raman spectroscopy for real-time monitoring of fed-batch penicillin production. Chem. Ing. Tech., 88 (2016) 764-776. doi:10.1002/cite.201500101.

[22] A. Ayer, J. Sandwald, B.A. Pillay, A.J. Meyer, G.G. Perrone, I.W. Dawes, Distinct redox regulation in sub-cellular compartments in response to various stress conditions in Saccharomyces cerevisiae. PLoS ONE, 8 (2013) e65240e65240. doi:10.1371/journal.pone.0065240. 
[23] J.P. Williams, J.E. Hallsworth, Limits to life in hostile environments: no barriers to biosphere function? Environ. Microbiol. $11 \quad$ (2009) 3292-3308. doi.org/10.1111/j.1462-2920.2009.02079.x.

[24] C. Huang, D.H. Zhu, H. Wu, W.Y. Lou, M.H. Zong, Evaluating the influence of inhibitors present in lignocellulosic hydrolysates on the cell membrane integrity of oleaginous yeast Trichosporon fermentans by flow cytometry, Process Biochem. 49 (2014) 395-401. doi.org/10.1016/j.procbio.2013.12.007.

[25] P. Puligundla, D. Smogrovicova, C. Mok, V.S.R. Obulam, A review of recent advances in high gravity ethanol fermentation, Renew. Energ. https://doi.org/10.1016/j.renene.2018.06.062. 


\section{List of Figures}

Figure 1. Scheme representing the two-stage yeast treatment composed by the acid treatment and yeast reactivation stages

Figure 2. Optical microscope images showing: A) Cells from the yeast cream collected from an ethanol distillery, B) yeast cells flocculation by L. fermentum and C) effective dispersion of yeast cells by the acid treatment

Figure 3. Pareto chart of the standardized effects for: A) Percentage of cell flocculation dispersion (PFD) and B) Percentage of non-viable cell (PNC)

Figure 4. Contour plot for: A) Percentage of cell flocculation dispersion (PFD) and B) Percentage of non-viable cell (PNC) as a function of $\mathrm{pH}$ and temperature (T)

Figure 5. Comparison between the relative logarithmic cell total concentration (full circles) and the relative logarithmic viable cell concentration (empty circles) in the yeast reactivation stage for the: A) first and C) second cycles of Experiment 1 and for the fermentation stage for the: B) first and D) second cycles of the same experiment.

Figure 6. Oxidation-reduction potential curve during the yeast reactivation and fermentation stages for the first cycle of Experiment 1 defined by the FFD design shown in Table 2.

Figure 7. Measured concentrations of A) sucrose (-口-), glucose (-口-), fructose (-凶-), $X_{t o t}$ $(-\bullet-), X_{v}\left(--_{-}\right)$and $P\left(-\mathbf{\Delta}_{-}\right)$, and B) acetic, $A c\left(-\diamond_{-}\right)$, lactic, $L a\left(-x_{-}\right)$and succinic, $S u(-*-)$ acids and glycerol ( $-\nabla-)$ for the second cycle of Experiment 1.

Figure 8. A) Pareto chart of the standardized effects and B) contour plot for cell viability.

Figure 9. Experimental data for the yeast reactivation stage and fermentation stage (Cells (घ); Substrate $(\boldsymbol{\Delta})$ and Ethanol $(\bullet))$ of Experiment 1 in the FFD design compared with the simulated concentration time curves (-): A) Yeast reactivation stage of the 
first cycle, B) fermentation stage of the first cycle, C) yeast reactivation stage of the second cycle, D) fermentation stage of the second cycle. 
Figure 1

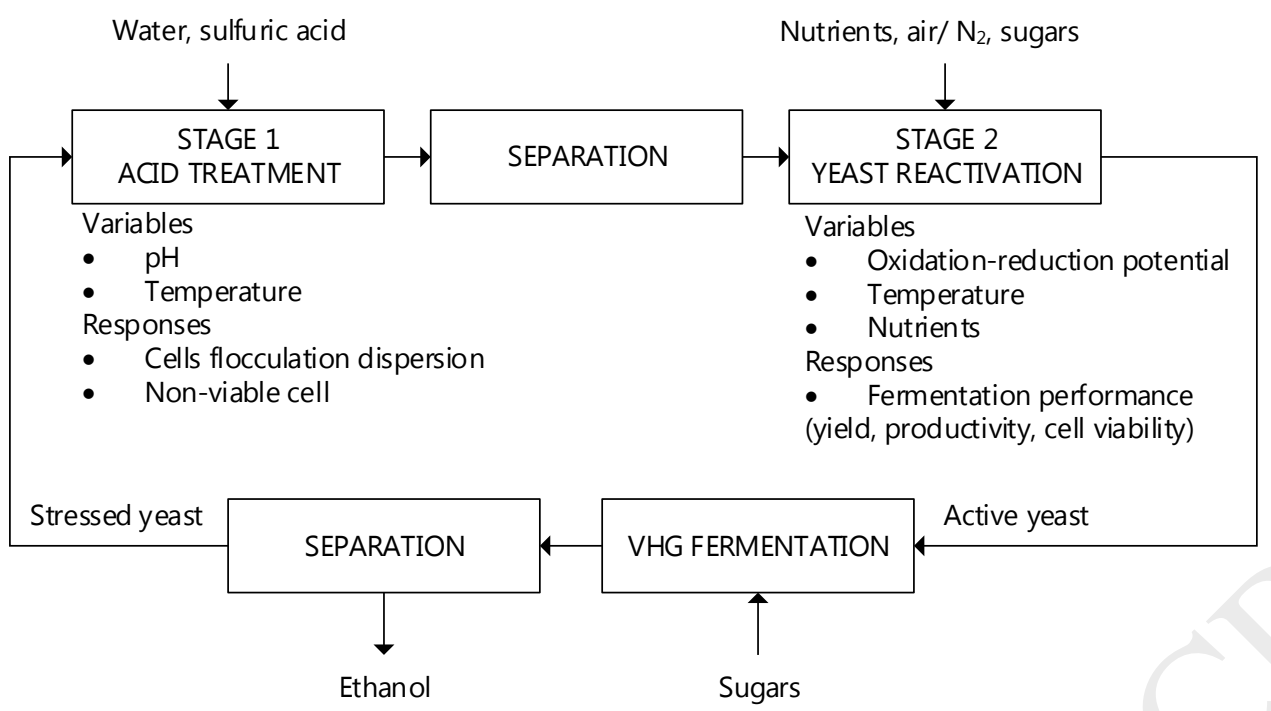


Figure 2

(A)

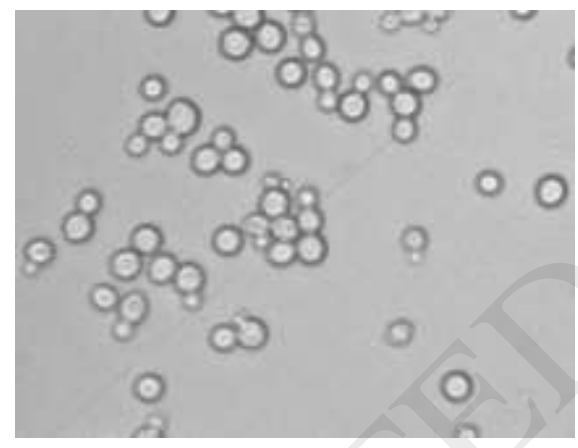

Figure 3
(B)

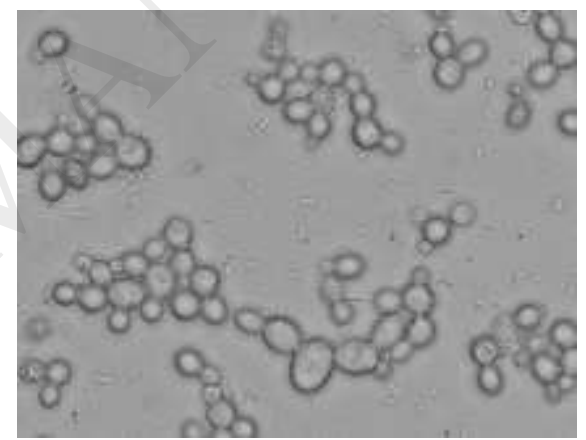

(C)

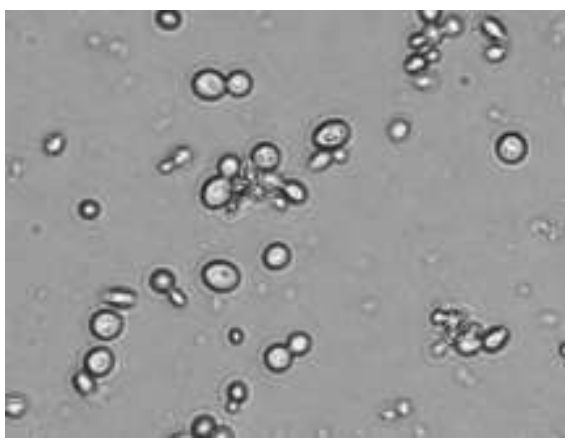


(A)

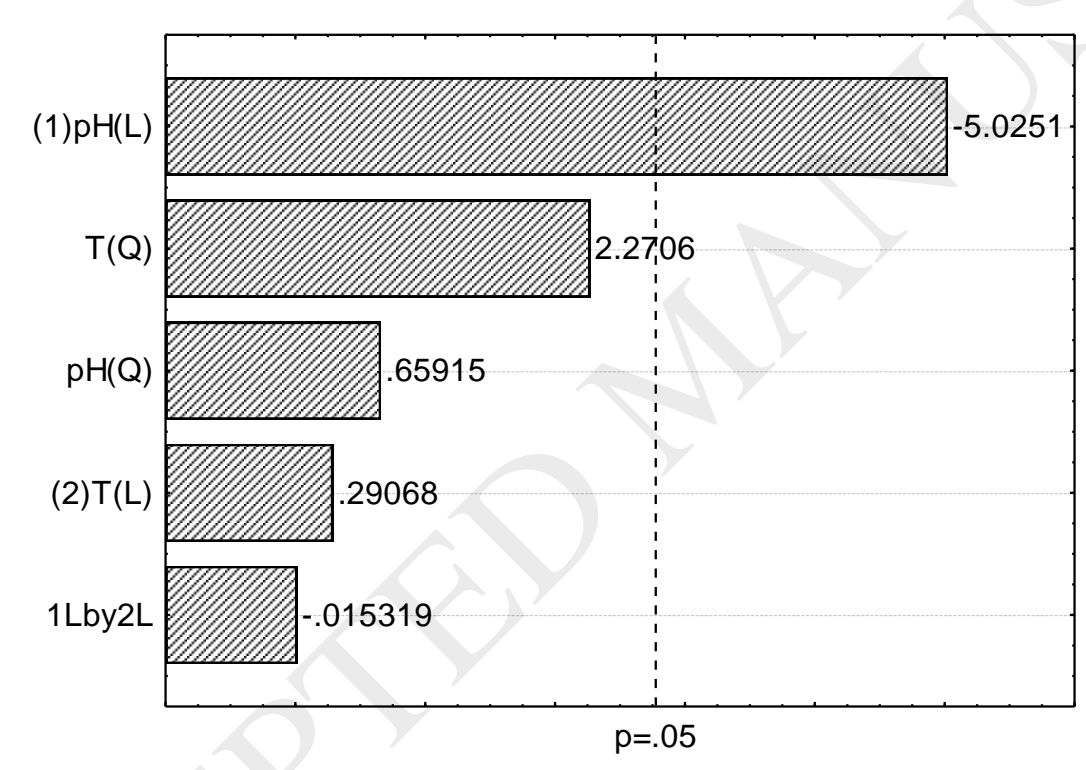

Standardized Effect Estimate (Absolute Value)
(B)

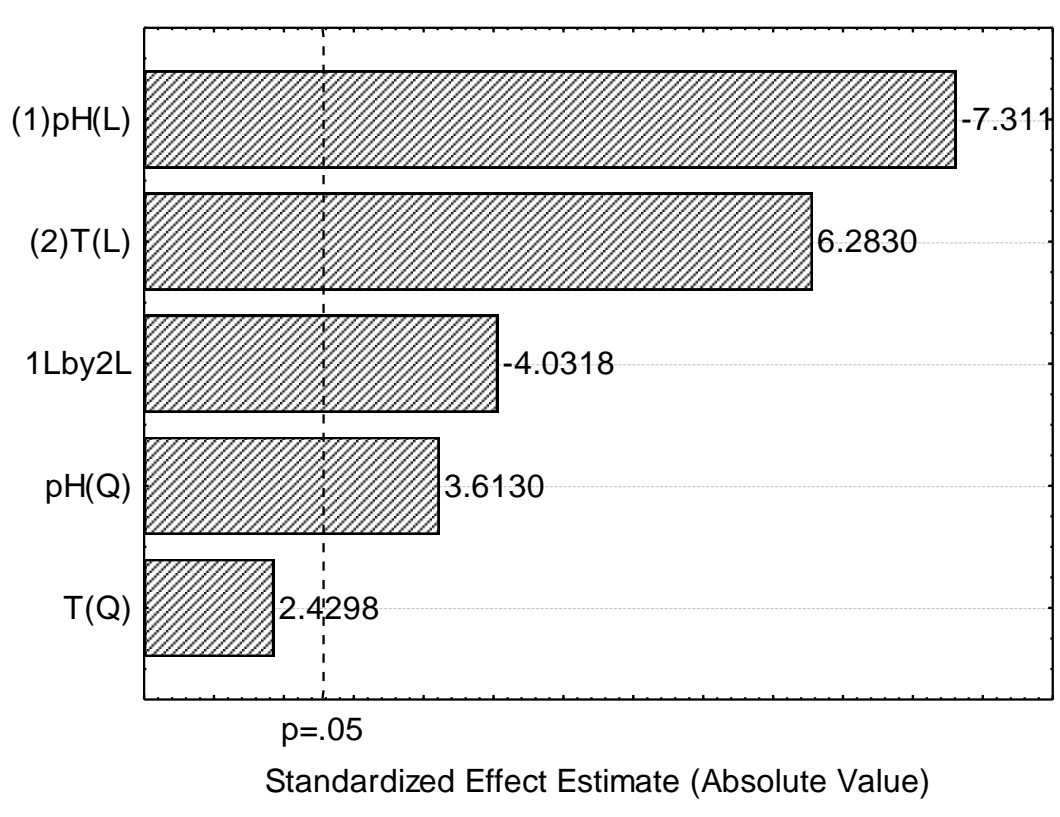

Figure 4 
(A)

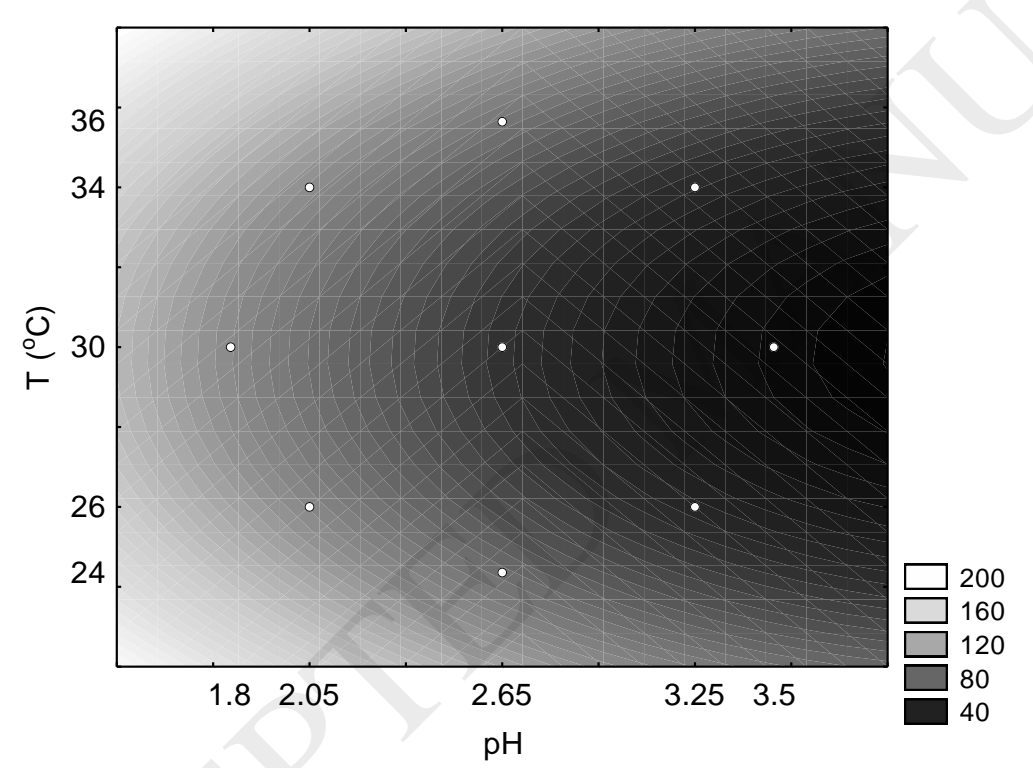

(B)

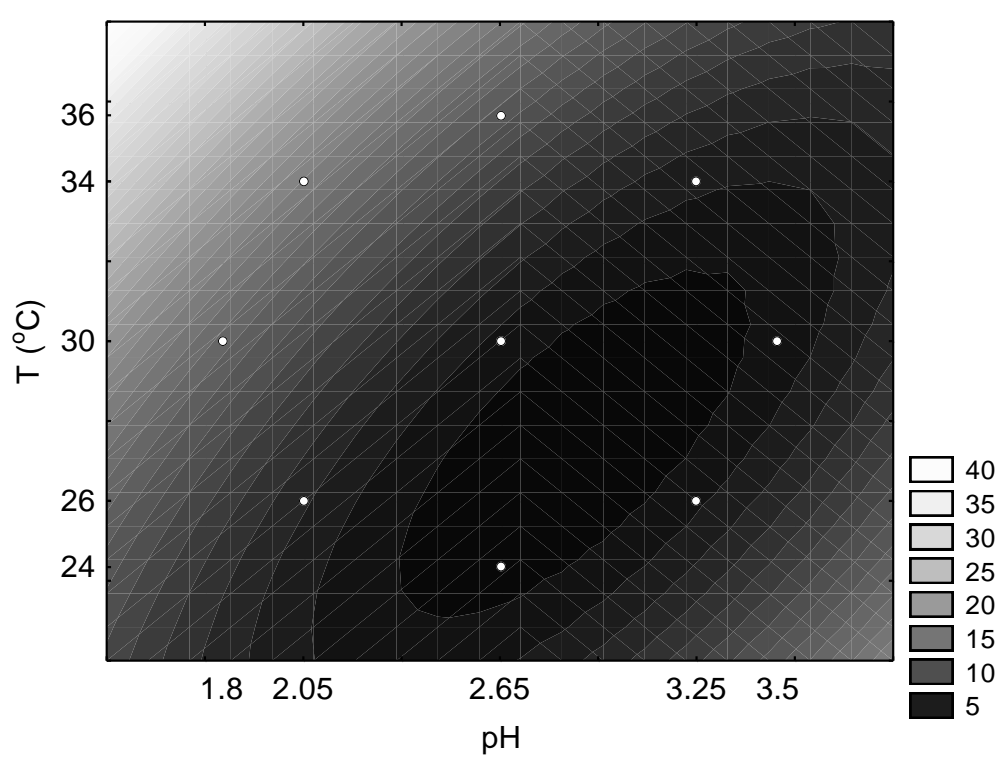

Figure 5 
(A)

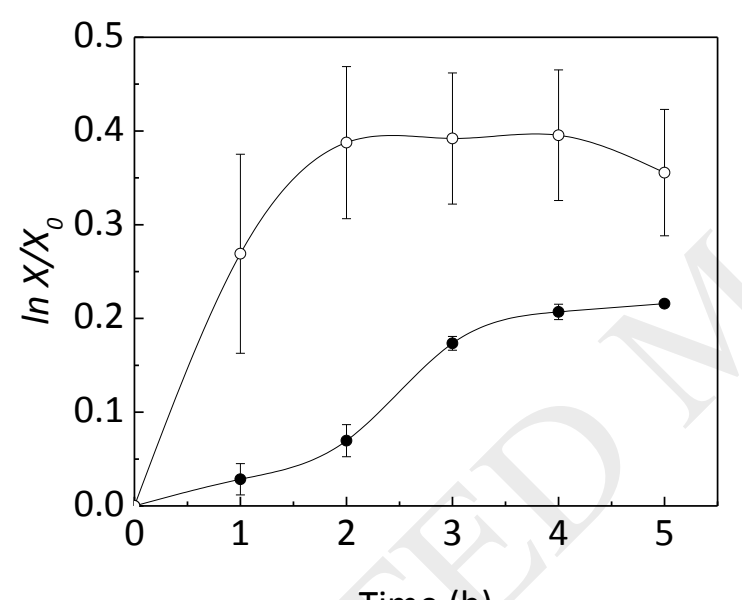

(C)

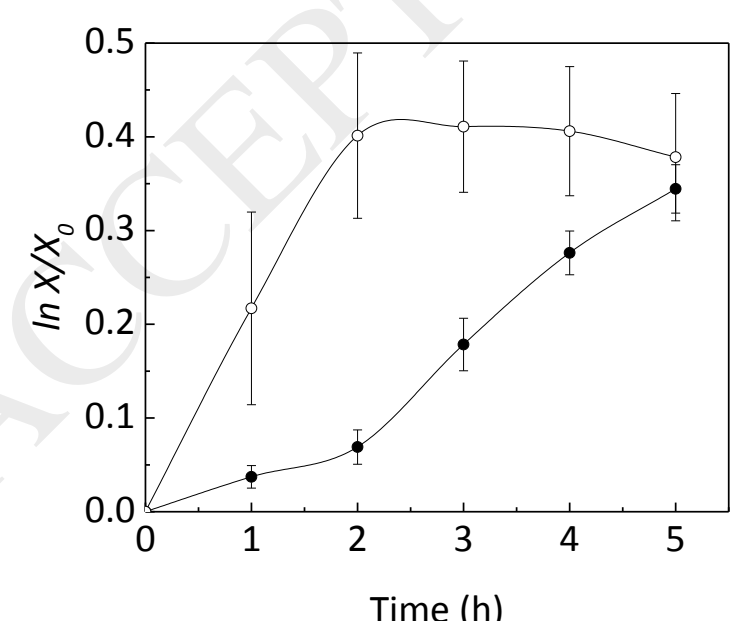

(B)

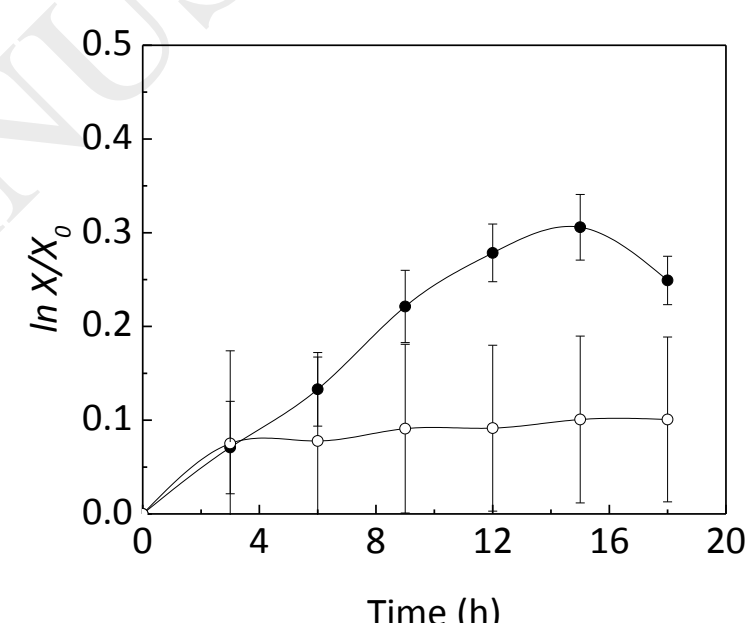

(D)

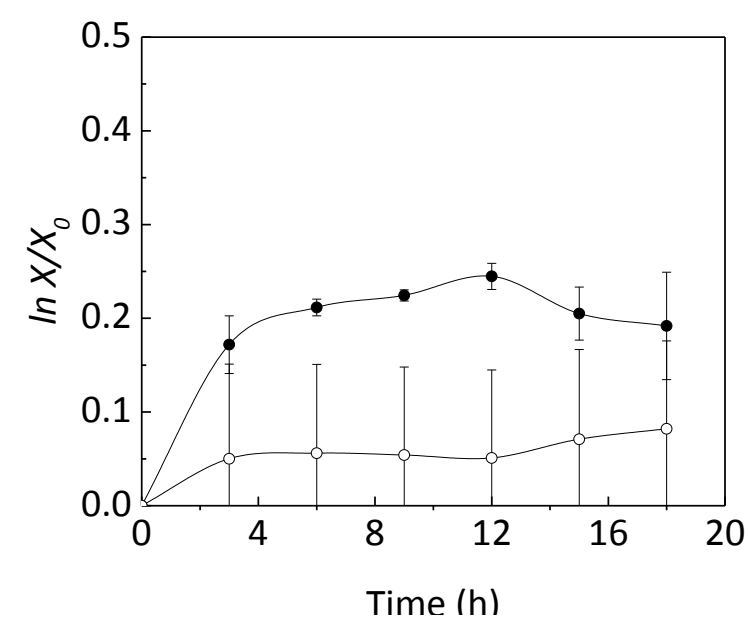


Figure 6

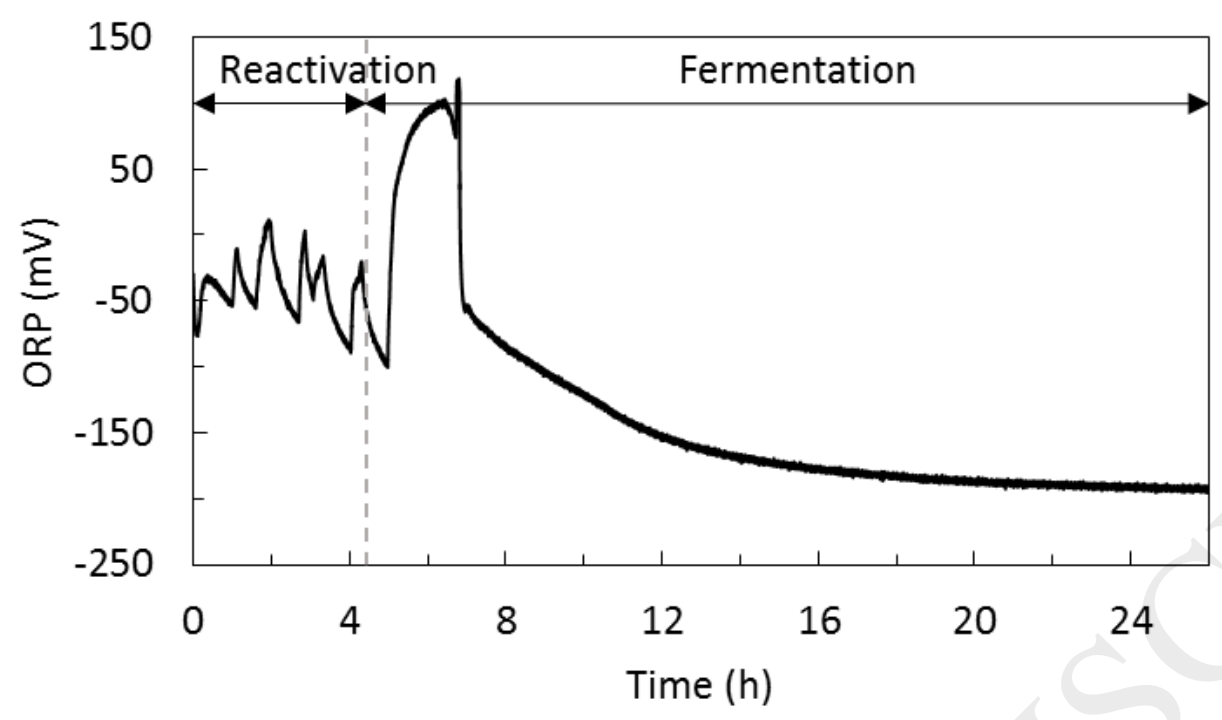


Figure 7

(A)

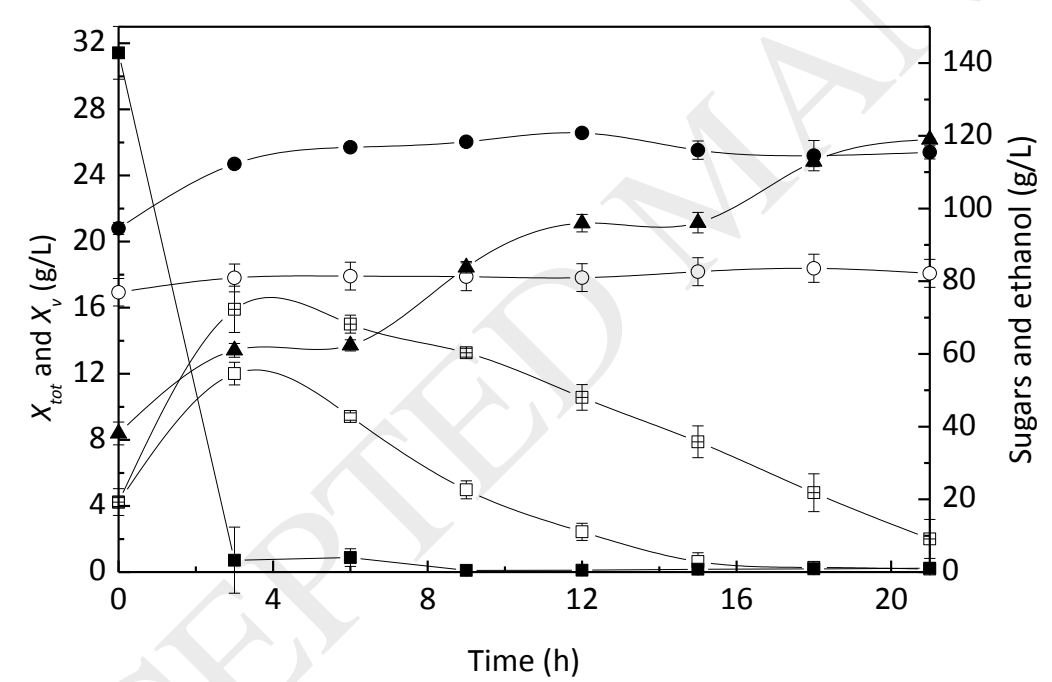

(B)

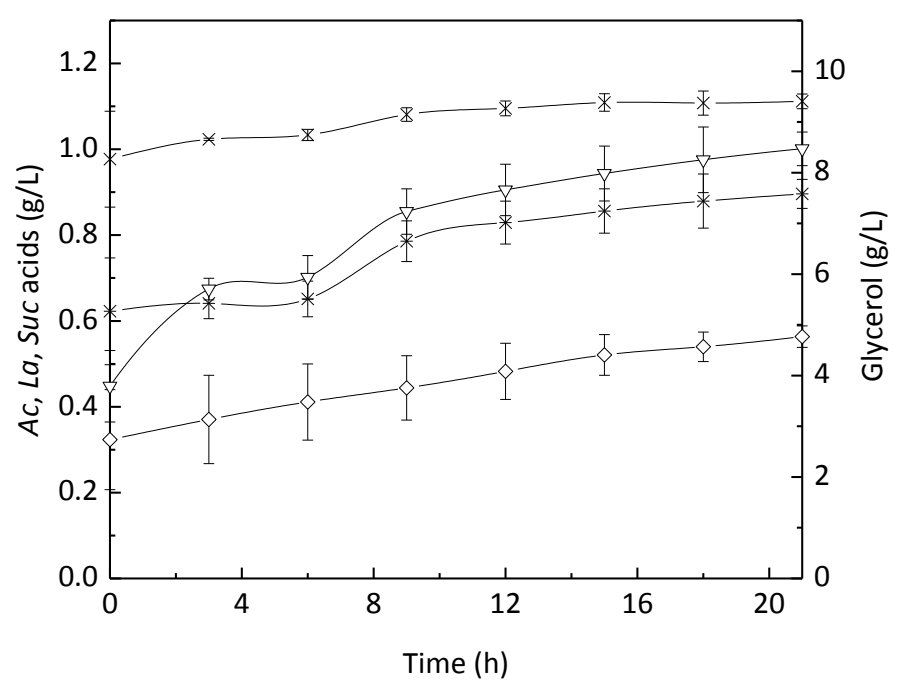

Figure 8 
(A)

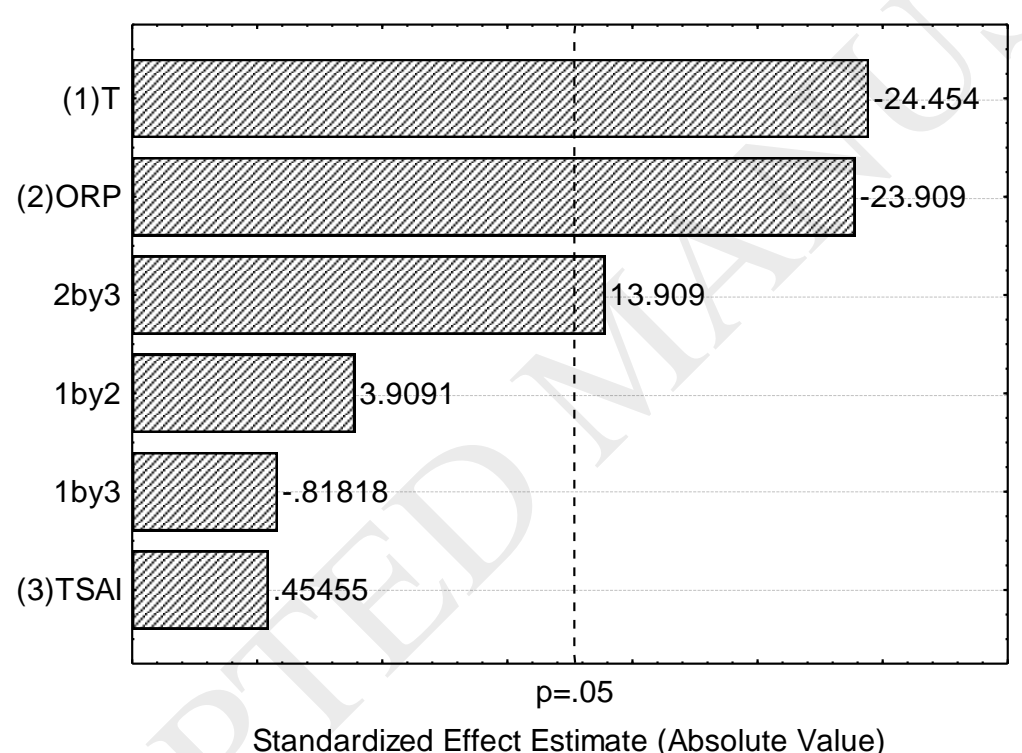

Standardized Effect Estimate (Absolute Value)
(B)

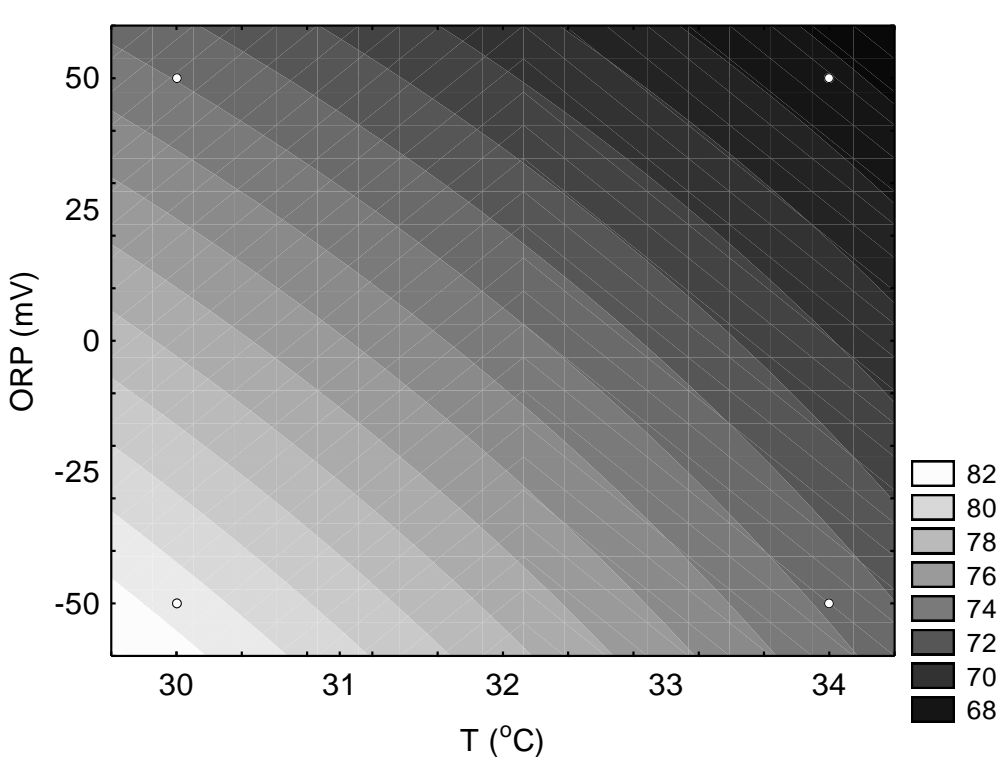

Figure 9

(A)

(B)

(C)

(D) 

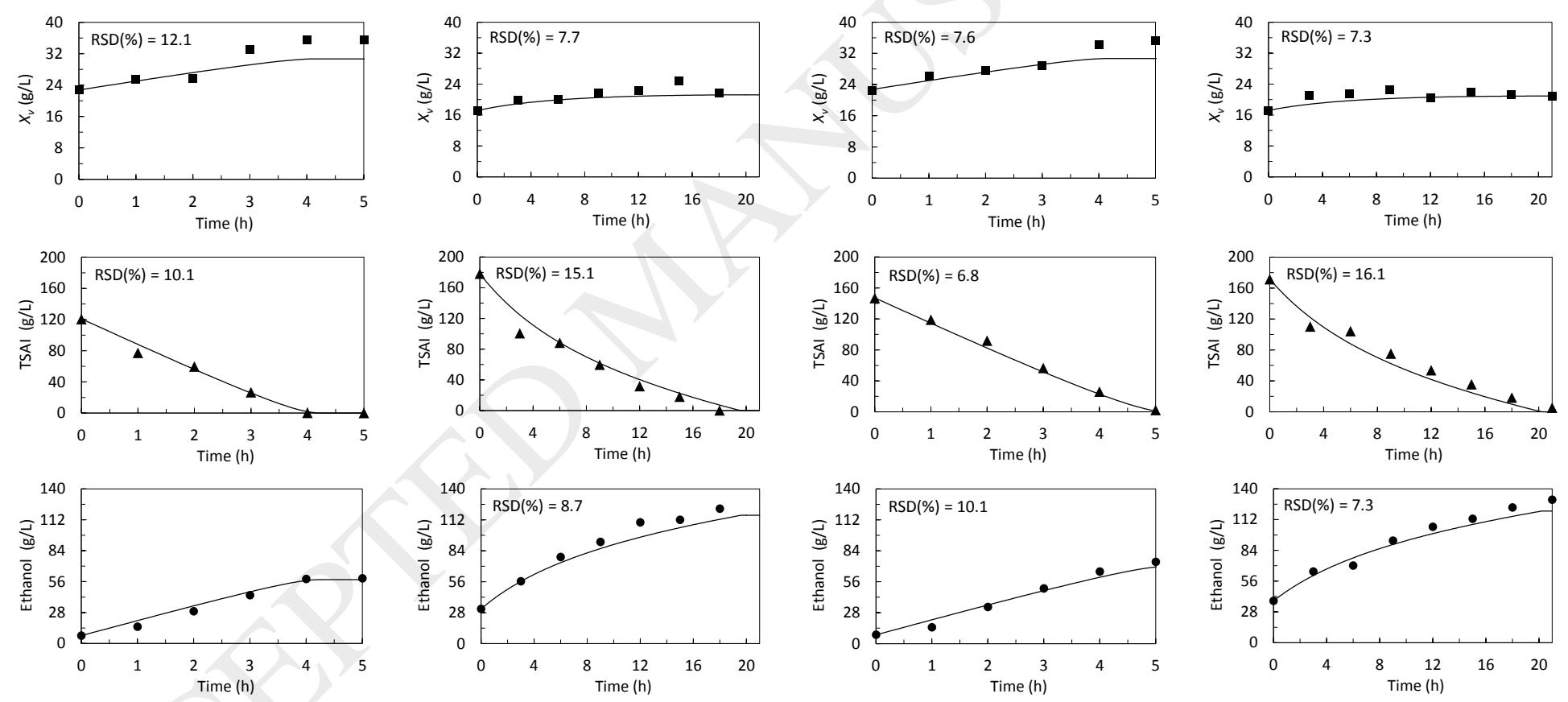
Table 1. Central composite design to study the acid treatment stage

\begin{tabular}{|c|c|c|c|c|c|c|}
\hline \multirow{2}{*}{ Exp. } & \multicolumn{2}{|c|}{ Coded parameters } & \multicolumn{2}{|c|}{ Operating parameters } & \multirow[t]{2}{*}{$\operatorname{PFD}(\%)^{*}$} & \multirow[t]{2}{*}{$\mathrm{PNC}(\%)^{*}$} \\
\hline & $\mathrm{X}_{1}$ & $\mathrm{X}_{2}$ & $\mathrm{pH}$ & $\mathrm{T}\left({ }^{\circ} \mathrm{C}\right)$ & & \\
\hline 1 & -1 & -1 & 2.05 & 26.0 & 99.3 & 4.1 \\
\hline 2 & -1 & 1 & 2.05 & 34.0 & 99.4 & 14.5 \\
\hline 3 & 1 & -1 & 3.25 & 26.0 & 27.2 & 3.9 \\
\hline 4 & 1 & 1 & 3.25 & 34.0 & 26.8 & 4.1 \\
\hline 5 & -1.4142 & 0 & 1.80 & 30.0 & 99.3 & 14.1 \\
\hline 6 & 1.4142 & 0 & 3.50 & 30.0 & 37.6 & 3.1 \\
\hline 7 & 0 & -1.4142 & 2.65 & 24.0 & 88.2 & 3.0 \\
\hline 8 & 0 & 1.4142 & 2.65 & 36.0 & 97.9 & 11.4 \\
\hline $9(\mathrm{C})$ & 0 & 0 & 2.65 & 30.0 & 47.3 & 3.7 \\
\hline $10(\mathrm{C})$ & 0 & 0 & 2.65 & 30.0 & 51.9 & 3.7 \\
\hline
\end{tabular}

\footnotetext{
* PFD and PNC at 60 min of acid treatment
} 
Table $2.2^{3}$ Full factorial design to study the yeast reactivation stage

\begin{tabular}{|c|c|c|c|c|c|c|}
\hline \multirow[t]{2}{*}{ Exp. } & \multicolumn{3}{|c|}{ Coded parameters } & \multicolumn{3}{|c|}{ Operating parameters } \\
\hline & $\mathrm{Y}_{1}$ & $\mathrm{Y}_{2}$ & $\mathrm{Y}_{3}$ & $\begin{array}{c}\mathrm{T} \\
\left({ }^{\circ} \mathrm{C}\right)\end{array}$ & $\begin{array}{l}\text { ORP } \\
(\mathrm{mV})\end{array}$ & $\begin{array}{l}\text { TSAI } \\
(\mathrm{g} / \mathrm{L})\end{array}$ \\
\hline 1 & -1 & -1 & -1 & 30 & -50 & 120 \\
\hline 2 & 1 & -1 & -1 & 34 & -50 & 120 \\
\hline 3 & -1 & 1 & -1 & 30 & 50 & 120 \\
\hline 4 & 1 & 1 & -1 & 34 & 50 & 120 \\
\hline 5 & -1 & -1 & 1 & 30 & -50 & 160 \\
\hline 6 & 1 & -1 & 1 & 34 & -50 & 160 \\
\hline 7 & -1 & 1 & 1 & 30 & 50 & 160 \\
\hline 8 & 1 & 1 & 1 & 34 & 50 & 160 \\
\hline
\end{tabular}


Table 3. Performance parameters of the yeast reactivation stage (first and second cycles) for each experiment defined by the full factorial design shown in Table 2

\begin{tabular}{|c|c|c|c|c|c|c|}
\hline \multirow{3}{*}{ Exp. } & \multicolumn{3}{|c|}{ Cell reactivation stage $-1^{\text {st }}$ cycle } & \multicolumn{3}{|c|}{ Cell reactivation stage $-2^{\text {nd }}$ cycle } \\
\hline & Productivity & Ethanol yield & Viability & Productivity & Ethanol yield & Viability \\
\hline & $\mathbf{g} /(\mathbf{L} \cdot \mathbf{h})$ & & $\%$ & $\mathbf{g} /(\mathbf{L} \cdot \mathbf{h})$ & $\mathrm{g} / \mathrm{g}$ & $\%$ \\
\hline 1 & 11.74 & 0.442 & 80.8 & 14.72 & 0.454 & 83.9 \\
\hline 2 & 11.60 & 0.434 & 70.7 & 15.94 & 0.470 & 74.0 \\
\hline 3 & 12.85 & 0.469 & 65.3 & 9.89 & 0.416 & 73.3 \\
\hline 4 & 9.66 & 0.388 & 62.3 & 8.46 & 0.399 & 65.1 \\
\hline 5 & 15.03 & 0.439 & 70.5 & 15.36 & 0.466 & 75.7 \\
\hline 6 & 12.90 & 0.434 & 76.7 & 12.89 & 0.421 & 76.4 \\
\hline
\end{tabular}




\begin{tabular}{lllllll}
\hline 7 & 11.03 & 0.364 & 76.1 & 11.56 & 0.412 & 73.3 \\
8 & 11.65 & 0.409 & 72.2 & 13.06 & 0.435 & 78.4 \\
\hline
\end{tabular}


Table 4. Performance parameters of the fermentation stage (first and second cycles) for each experiment defined by the full factorial design shown in Table 2

\begin{tabular}{|c|c|c|c|c|c|c|}
\hline \multirow[b]{2}{*}{ Exp. } & \multicolumn{3}{|c|}{ Fermentation stage $-1^{\text {st }}$ cycle } & \multicolumn{3}{|c|}{ Fermentation stage $-2^{\text {nd }}$ cycle } \\
\hline & Productivity & Ethanol yield & Viability & Productivity & Ethanol yield & Viability \\
\hline & $\mathbf{g} /(\mathbf{L} \cdot \mathbf{h})$ & & $\%$ & $\mathbf{g} /(\mathbf{L} \cdot \mathbf{h})$ & $\mathbf{g} / \mathbf{g}$ & $\%$ \\
\hline 1 & 5.31 & 0.419 & 78.0 & 4.58 & 0.425 & 82.2 \\
\hline 2 & 5.19 & 0.434 & 69.5 & 4.55 & 0.407 & 74.9 \\
\hline 3 & 4.52 & 0.372 & 66.2 & 3.97 & 0.406 & 71.0 \\
\hline 4 & 4.68 & 0.365 & 66.7 & 4.15 & 0.385 & 65.3 \\
\hline 5 & 4.07 & 0.449 & 67.2 & 4.02 & 0.428 & 70.7 \\
\hline 6 & 4.21 & 0.420 & 76.2 & 4.26 & 0.405 & 79.0 \\
\hline
\end{tabular}




\begin{tabular}{lllllll}
\hline 7 & 4.36 & 0.354 & 66.5 & 4.02 & 0.389 & 69.3 \\
8 & 3.91 & 0.375 & 67.7 & 4.15 & 0.412 & 74.9 \\
\hline
\end{tabular}

Table 5. Optimal kinetic parameters of the model for each condition defined by the full factorial design shown in Table 2

\begin{tabular}{|c|c|c|c|c|c|c|c|c|c|c|c|c|}
\hline \multirow[t]{2}{*}{ Exp. } & \multicolumn{6}{|c|}{ Yeast reactivation stage } & \multicolumn{6}{|c|}{ VHG fermentation stage } \\
\hline & $\mu_{\max }$ & $X_{\max }$ & $P_{\max }$ & $Y_{p / x}$ & $Y_{x}$ & $k_{i}$ & $\mu_{\max }$ & $X_{\max }$ & $P_{\max }$ & $Y_{p / x}$ & $Y_{x}$ & $k_{i}$ \\
\hline 1 & 0.128 & 172.5 & 214.9 & 5.0 & $8.1 \times 10^{-2}$ & $1.31 \times 10^{-4}$ & 0.209 & 25.9 & 127.8 & 11.11 & $4.10 \times 10^{-2}$ & $1.92 \times 10^{-5}$ \\
\hline 3 & 0.125 & 191.2 & 222.3 & 3.8 & $1.08 \times 10^{-1}$ & $1.31 \times 10^{-4}$ & 0.116 & 24.1 & 132.6 & 15.86 & $3.33 \times 10^{-2}$ & $6.53 \times 10^{-6}$ \\
\hline 4 & 0.137 & 186.5 & 177.7 & 4.3 & $8.63 \times 10^{-2}$ & $1.05 \times 10^{-4}$ & 0.090 & 40.8 & 121.2 & 14.52 & $3.53 \times 10^{-2}$ & $5.76 \times 10^{-5}$ \\
\hline 5 & 0.127 & 172.5 & 215.4 & 7.2 & $6.97 \times 10^{-2}$ & $9.83 \times 10^{-5}$ & 0.189 & 27.7 & 125.0 & 10.00 & $4.72 \times 10^{-2}$ & $5.38 \times 10^{-6}$ \\
\hline 7 & 0.193 & 176.1 & 137 & 3.3 & $1.06 \times 10^{-1}$ & $2.23 \times 10^{-4}$ & 0.107 & 42.2 & 122.3 & 11.32 & $4.35 \times 10^{-2}$ & $1.61 \times 10^{-5}$ \\
\hline 8 & 0.147 & 175.9 & 219.4 & 3.5 & $1.12 \times 10^{-1}$ & $3.34 \times 10^{-4}$ & 0.091 & 29.8 & 132.6 & 15.00 & $3.20 \times 10^{-2}$ & $2.42 \times 10^{-5}$ \\
\hline
\end{tabular}

